Numerical Modeling of Coupled Groundwater and Surface Water Interactions in an Urban Setting

Jehan F. Rihani, Reed M. Maxwell

September 28, 2007 
This document was prepared as an account of work sponsored by an agency of the United States Government. Neither the United States Government nor the University of California nor any of their employees, makes any warranty, express or implied, or assumes any legal liability or responsibility for the accuracy, completeness, or usefulness of any information, apparatus, product, or process disclosed, or represents that its use would not infringe privately owned rights. Reference herein to any specific commercial product, process, or service by trade name, trademark, manufacturer, or otherwise, does not necessarily constitute or imply its endorsement, recommendation, or favoring by the United States Government or the University of California. The views and opinions of authors expressed herein do not necessarily state or reflect those of the United States Government or the University of California, and shall not be used for advertising or product endorsement purposes.

This work was performed under the auspices of the U.S. Department of Energy by University of California, Lawrence Livermore National Laboratory under Contract W-7405-Eng-48. 


\title{
Numerical Modeling of Coupled Groundwater and Surface Water Interactions in an Urban Setting
}

\author{
Jehan F. Rihani \\ Department of Civil and Environmental Engineering \\ University of California, Berkeley \\ Reed M. Maxwell \\ Atmospheric, Earth and Energy Sciences Department \\ Lawrence Livermore National Laboratory
}

This work was performed under the auspices of the U.S. Department of Energy by University of California, Lawrence Livermore National Laboratory under Contract W-7405-Eng-48. This work was funded by the FE program of the U. S. Department of Energy. 


\section{TABLE OF CONTENTS}

\section{Page}

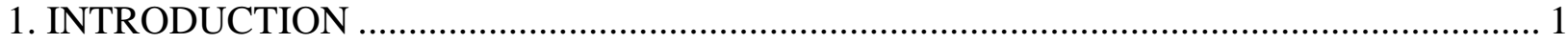

1.1 The Dominguez Channel Watershed ………………......................................................... 1

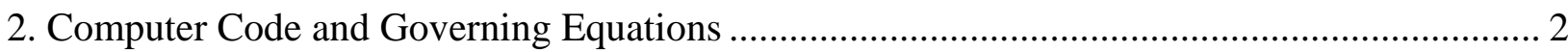

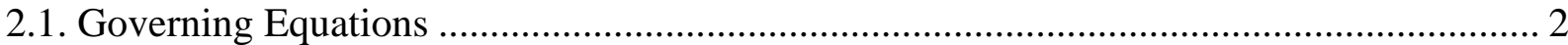

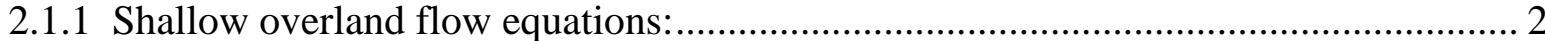

2.1.2 Variably saturated GW flow:.................................................................................... 3

2.1.3 Boundary Condition at the Land Surface.................................................................... 3

3. Watershed Discretization and Model Design …………........................................................... 3

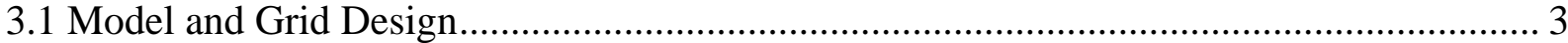

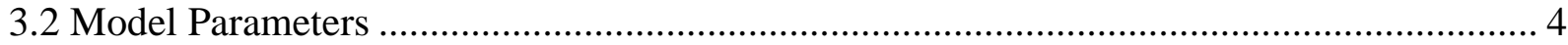

3.3 Sources, Sinks and Simulation Time ……………..................................................... 4

3.4 Initial and Boundary Conditions ...................................................................................... 5

4. Flow Model Calibration and Parameter Sensitivities ………..................................................... 5

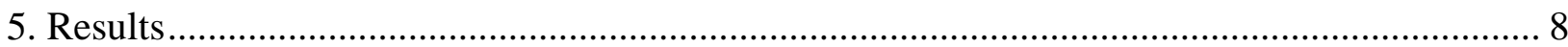

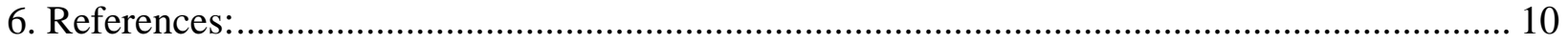

APPENDIX A: Dominguez Channel Watershed............................................................................ 11

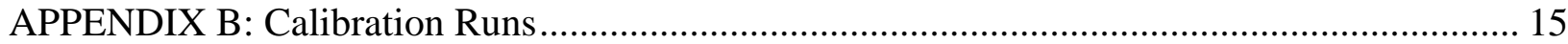




\section{LIST OF FIGURES}

Page

Figure 1: Conceptual model of Dominguez Channel watershed ................................................... 4

Figure 2: (a) Digital elevation model for the Dominguez channel watershed............................... 5

(b) Digital elevation model (converted to a three-dimensional solid file)...................... 5

Figure 3: Processed slope vectors calculated from the Dominguez Channel

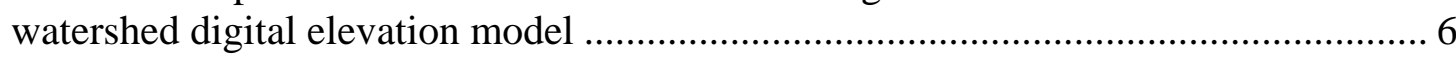

Figure 4: Radar and rain gage storm data along with the resulting observed hydrograph at DCW ................................................................................. 6

Figure 5: Calibrated Saturated Hydraulic Conductivity Field in $\mathrm{m} / \mathrm{hr}$ (log scale) of Dominguez Channel watershed ............................................................... 8

Figure 6: Calibrated Porosity Field of Dominguez Channel watershed

Figure 7: The calibrated hydrograph (run72) and runs with rain gage rainfall data for the same storm

Figure A1: Regional map showing the location of the Dominguez Channel

Watershed (MEC, 2004)

Figure A.2: Cities and zip codes within the Dominguez Watershed (MEC, 2004)..................... 12

Figure A.3: Isohyetal Map of precipitation (associated with a 50-year, 24-hour rainfall design storm) for the Dominguez Channel Watershed

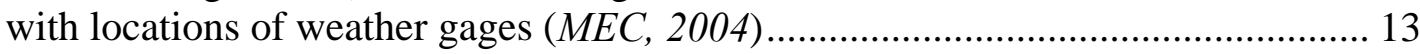

Figure A.4: Dominguez Channel Watershed topography (MEC, 2004) ..................................... 14

Figure B.1: Comparison of runs with (run49) or without (run21) a subsurface layer assigned.

Figure B.2: Comparison of runs with different vertical cell size; run34

$(\mathrm{dz}=0.2)$ and run35 $(\mathrm{dz}=0.1)$

Figure B.3: Comparison of runs with different Channel Manning's Coefficient; run70 (1.0E-7), run72 (2.0E-7), and run71 (3.0E-7)

Figure B.4: Comparison of runs with different field Manning's Coefficient; run51 (1.0E-6), run52 (5.0E-6), and run49 (2.0E-5)

Figure B.5: Comparison of runs with different channel porosity; run70 (0.00009) and run69 (0.0001)...

Figure B.6: Comparison of runs with different field porosity; run30 (0.001) and run21 (0.01)

Figure B.7: Comparison of runs with different subsurface porosity; run57 (0.01) and run59 (0.2)

Figure B.8: Comparison of runs with different field hydraulic conductivity; run55 (0.0005), run54 (0.001), and run53 (0.003).

Figure B.9: Comparison of runs with different surface layer thickness; run54 (1 layer), run57 (2 layers), and run65 (3 layers).

Figure B.10: Comparison of runs with different field slopes; run37 (0.5*processed field slopes), run45 (0.25*processed field slopes), and run46 (0.05*processed field slopes). 


\section{LIST OF TABLES}

\section{Page}

Table 1: Summary of land use within the Dominguez Channel Watershed

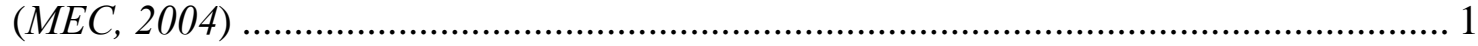

Table 2: Model Domain and Grid ........................................................................................ 3

Table 3: Summary of parameter sensitivity runs with reference to

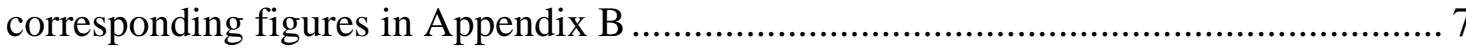

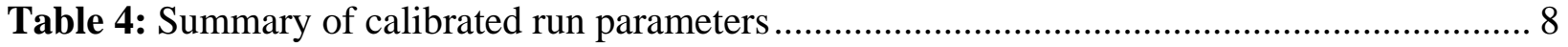

Table B.1: Record of calibration runs and mass balance calculations..................................... 15 


\section{INTRODUCTION}

\subsection{The Dominguez Channel Watershed}

The Dominguez Channel Watershed (DCW), located in the southern portion of Los Angeles County (Figure A.1), drains about 345 square miles into the Los Angeles Harbor. The cities and jurisdictions in DCW are shown in Figure A.2. The largest of these include the cities of Los Angeles, Carson, and Torrance. This watershed is unique in that 93\% of its land area is highly developed (i.e. urbanized). The watershed boundaries are defined by a complex network of storm drains and flood control channels, rather than being defined by natural topography. Table (1) shows a summary of different land uses in the Dominguez Channel Watershed (MEC, 2004).

Table (1): Summary of land use within the Dominguez Channel Watershed $(M E C, 2004)$.

\begin{tabular}{|l|c|c|c|}
\hline Land Use & Area $\left(\mathbf{k m}^{\mathbf{2}}\right)$ & Area $\left(\mathbf{m i}^{\mathbf{2}}\right)$ & Percent of Total \\
\hline Education & 10.5 & 4.1 & 3.1 \\
\hline $\begin{array}{l}\text { High Density Single Family } \\
\text { Residential }\end{array}$ & 100.3 & 38.7 & 29.1 \\
\hline Multi-Family Residential & 16.6 & 6.4 & 4.8 \\
\hline Mixed Residential & 12.1 & 4.7 & 3.5 \\
\hline Industrial & 86.8 & 33.5 & 25.2 \\
\hline Retail/Commercial & 35.5 & 13.7 & 10.3 \\
\hline Transportation & 16.7 & 6.5 & 4.8 \\
\hline Vacant & 34.1 & 13.2 & 9.9 \\
\hline Harbor Waters & 32.9 & 12.7 & 9.5 \\
\hline TOTAL & 345 & 133 & 100 \\
\hline
\end{tabular}

The Dominguez Watershed has the highest impervious area of all watersheds in the Los Angeles region. The more impervious the surface, the more runoff is generated during a storm. Storm water runoff can carry previously accumulated contaminants and transport them into receiving water systems. Point sources such as industrial wastewater and municipal sewage as well as urban runoff from commercial, residential, and industrial areas are all recognized as contributors to water quality degradation at DWC.

Section 303(d) of the 1972 Federal Clean Water Act (CWA) requires states to identify and report all waters not meeting water quality standards and to develop action plans to pursue the water quality objectives. These plans specify the maximum amount of a given pollutant that the water body of concern can receive and still meet water quality standards. Such plans are called Total Maximum Daily Loads (TMDLs). TMDLs also specify allocations of pollutant loadings to point and non-point sources taking into account natural background pollutant levels. This demonstrates the importance of utilizing scientific tools, such as flow and transport models, to identify contaminant sources, understand integrated flow paths, and assess the effectiveness of water quality management strategies. 
Since overland flow is a very important component of the water balance and hydrology of DCW, a parallel, distributed watershed model that treats flow in groundwater and surface water in a dynamically coupled manner will be used to build a flow model of the watershed. This coupled model forms the basis for modeling and understanding the transport of contaminants through the Dominguez Channel Watershed, which can be used in designing and implementing TMDLs to manage the water quality in this basin.

In this report, the coupled surface water-groundwater flow model of DCW will be presented. This flow model was calibrated against a storm that occurred in February $21^{\text {st }}, 2004$. The model and approach are explained further in the following sections.

\section{Computer Code and Governing Equations}

To better simulate the interactions between surface water and groundwater at DCW, the parallel three dimensional variably saturated subsurface flow code Parflow (Ashby and Falgout, 1996; Jones and Woodward, 2001), coupled to a new two-dimensional overland flow simulator (Kollet and Maxwell, 2006), was used in modeling this watershed. This new coupled approach does not rely on the conductance concept (e.g. Anderson and Woessner, 1992) usually utilized in such applications. Instead, it directly couples the surface and subsurface systems via a boundary condition applied at the ground surface.

The system of equations being coupled in this new formulation is briefly described in Section 2.1, which shows how Parflow utilizes conditions of pressure and flux continuity at the ground surface to implement the overland flow equations into the Richard's equation when the upper boundary cell becomes saturated. For complete details, the reader is referred to Kollet and Maxwell (2006).

\subsection{Governing Equations}

\subsubsection{Shallow overland flow equations:}

The Continuity equation can be written as follows for a two dimensional problem (Kollet and Maxwell, 2006):

$$
\frac{\partial \psi_{s}}{\partial t}=\nabla \vec{v} \psi_{s}+q_{r}(x)
$$

Where; $v$ is the depth averaged velocity vector $[\mathrm{L} / \mathrm{T}], \psi_{s}$ is the surface ponding depth [L], $q_{r}(x)$ is the general source/sink rate $[\mathrm{L} / \mathrm{T}]$. This formulation neglects the vertical change in momentum since the flow depth is vertically averaged. When diffusion terms are neglected, the momentum equation simplifies to the kinematic wave approximation (Kollet and Maxwell, 2006):

$$
S_{f, i}=S_{o, i}
$$


Where; $\mathrm{S}_{f, i}$ is the friction slope in the x or y direction [L], $S_{o, i}$ is the bed slope or gravity forcing term [-], and $i$ stands for the $\mathrm{x}$ and y directions. Manning's equation is used to obtain a flow depth - discharge relationship (Kollet and Maxwell, 2006):

$$
v_{x}=\frac{\sqrt{S_{f, x}}}{n} \psi_{s}^{2 / 3} \quad \text { and } \quad v_{y}=\frac{\sqrt{S_{f, y}}}{n} \psi_{s}^{2 / 3}
$$

Where; $n$ is Manning's friction coefficient $\left[\mathrm{T} / \mathrm{L}^{1 / 3}\right]$.

\subsubsection{Variably saturated GW flow:}

Richard's equation is used to model variably saturated groundwater flow (Jones and Woodward, 2001; Kollet and Maxwell, 2006):

$$
\begin{gathered}
S_{s} S_{w} \frac{\partial \psi_{p}}{\partial t}+\phi \frac{\partial S_{w}\left(\psi_{p}\right)}{\partial t}=\nabla \cdot q+q_{s} \\
\quad \text { (Equation 4) } \\
q=-k(x) k_{r}\left(\psi_{p}\right) \nabla\left(\psi_{p}-z\right)
\end{gathered}
$$

Table (2): Model Domain and Grid.

Where; $z$ is depth below the surface [L], $\psi_{p}$ is the subsurface pressure head [L], $k(x)$ is the saturated hydraulic conductivity [L/T], $k r$ is the relative permeability [-], $S_{s}$ is the specific storage coefficient $\left[\mathrm{L}^{-1}\right], \phi$ is the

\begin{tabular}{|l|c|c|c|}
\cline { 2 - 4 } \multicolumn{1}{c|}{} & \multicolumn{3}{c|}{ Model Coordinates } \\
\cline { 2 - 4 } \multicolumn{1}{c|}{} & $\mathbf{X}(\mathbf{m})$ & $\mathbf{Y}(\mathbf{m})$ & $\mathbf{Z}(\mathbf{m})$ \\
\hline Upper $\mathbf{x}, \mathbf{y}$, or $\mathbf{z}$ & $23,939.8$ & $17,721.7$ & 2.0 \\
\hline Lower $\mathbf{x}, \mathbf{y}$, or $\mathbf{z}$ & 0 & 0 & 0 \\
\hline $\mathbf{d x}, \mathbf{d y}$, or $\mathbf{d z}(\mathbf{m})$ & 310.907 & 310.907 & 0.1 \\
\hline $\mathbf{n x}, \mathbf{n y}$, or $\mathbf{n z}$ & 57 & 77 & 20 \\
\hline
\end{tabular}
porosity [-], $S_{w}$ is the Degree of saturation [-], and $q_{s}$ is the general source/sink term $\left[\mathrm{T}^{-1}\right]$

\subsubsection{Boundary Condition at the Land Surface}

Continuity of pressure $\left(\psi_{p}=\psi_{s}=\psi\right)$ and flux $\left(q_{b c}=q_{e}\right)$ at the ground surface gives the boundary condition at the land surface (Kollet and Maxwell, 2006):

$$
-k(x) k_{r} \nabla(\psi-z)=\frac{\partial\|\psi \cdot 0\|}{\partial t}-\nabla \vec{v}\|\psi \cdot 0\|-q_{r}(x)
$$

\section{Watershed Discretization and Model Design}

\subsection{Model and Grid Design}

The Dominguez Channel watershed was simulated within a box-shaped domain with dimensions of about $17.7 \mathrm{~km}$ by $23.9 \mathrm{~km}$ by $2 \mathrm{~m}$ in the $\mathrm{x}-$, $\mathrm{y}$-, and $\mathrm{z}$-directions, respectively 
(Table 2). Figure (1) shows the conceptual model of DCW. The black area around the watershed in figure (1) consists of inactive cells. No flow or pressure is calculated within these cells. Simulation only takes place in the active cell region within the watershed boundaries shown in the same figure.

The top three layers of the active domain represent the urbanized land surface and the Dominguez channel. Active cells beneath those surface layers were assigned as the subsurface beneath

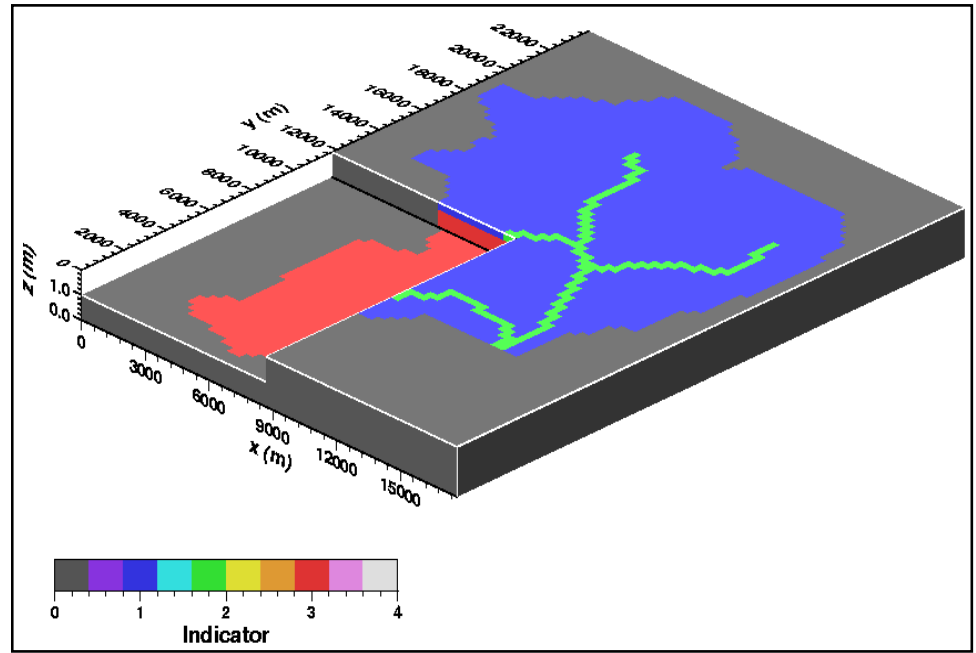

Figure (1): Conceptual model of Dominguez Channel watershed. DCW. Thus, three different sets of land/soil properties where introduced into the model and calibration process. This was introduced by means of an indicator field, which can be used in the same way to introduce more different land use types to the surface and more heterogeneity in the subsurface, if required.

\subsection{Model Parameters}

Based on the conceptual model and formulation described previously, the model parameters assigned are; hydraulic conductivities and porosities for field, channel, and subsurface, Manning's coefficients for the field and channel, specific storage, relative permeability parameters, and surface slopes. The slopes were calculated (as x- and y-slopes) based on the DCW digital elevation model (Figure 2). To prevent numerical instabilities, these slopes were processed to eliminate sinks in the surface. Figure 3 shows the resulting processed slope vectors used in the model enlarged 10 times. Finally, the Van Genuchten equations (Van Genuchten, 1980) were used to describe the relative saturation and permeability.

This formulation allows for the urbanization of the surface to be taken into account, by assigning low hydraulic conductivity and porosity for the field and even lower values to the concrete channel, while still being able to assign reasonable subsurface parameters to allow for infiltration and water table fluctuations.

\subsection{Sources, Sinks and Simulation Time}

The model was calibrated against observed outflow in the DCW resulting from a storm event that occurred on February, $21^{\text {st }} 2004$. Time variable rainfall radar data was obtained from the National Oceanic and Atmospheric Administration's (NOAA) National Weather Service (NWS) using the Stage III assimilated precipitation product. Furthermore, the watershed has three rainfall gages within its boundaries; One at Los Angeles International Airport (LAX), one 
within the center of the watershed, and one at the outlet (Figure A.3). Since the radar data is averaged over the entire watershed area, once the model was calibrated it was run using the each of the three rain gage data to verify that the model behavior envelopes the spatial variability in rainfall. Figure (4) shows the radar rainfall data as well as the rain gage data. The recorded hydrograph of that storm is also shown in the figure. No evaporation was assumed during the storm simulation. Also, based on the Feb $21^{\text {st }}$ storm, the simulations were set to 27 hours with 5 minute time steps.

\subsection{Initial and Boundary Conditions}

Nuemann-type boundary conditions are applied for the DCW model. For the perimeter and bottom boundary, no flow conditions were applied. The overland flow boundary condition was applied at the top layer. As for initial conditions, the water table was assigned at the bottom layer of the domain at the beginning of the simulation.

\section{Flow Model Calibration and Parameter Sensitivities}

The model was calibrated under transient conditions against the

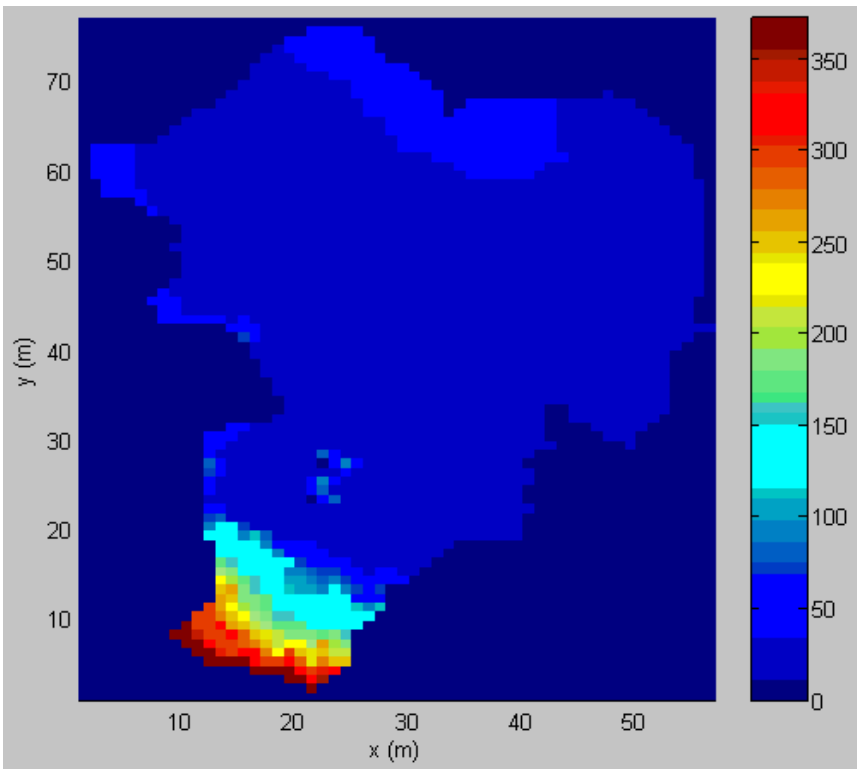

Figure (2a): Digital elevation model for the Dominguez channel watershed.

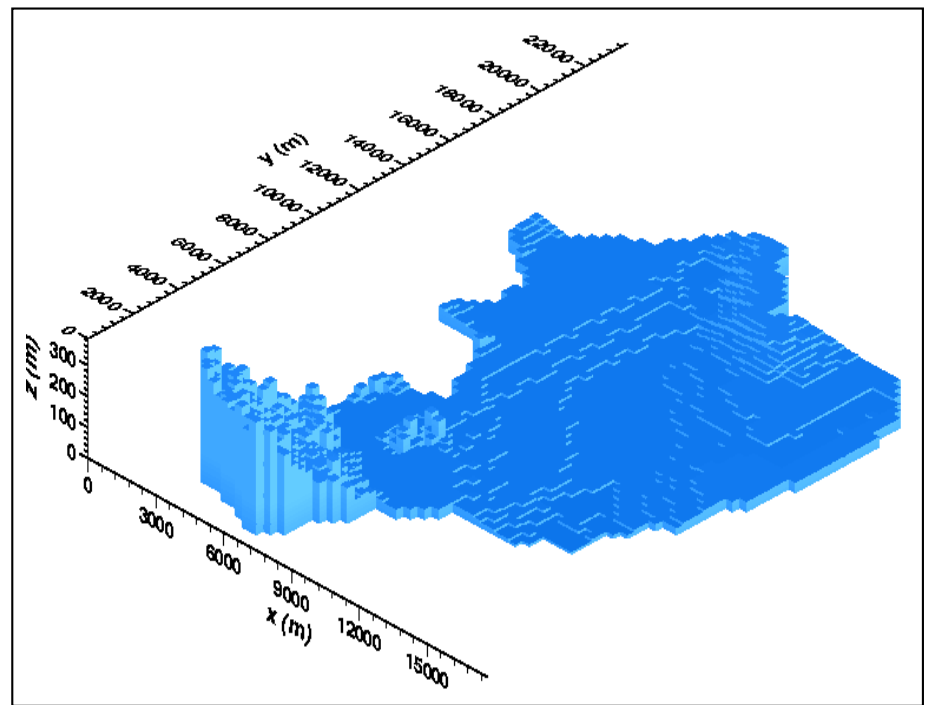

Figure (2b): Digital elevation model (converted to a three-dimensional solid file) radar rainfall data for the Feb. $21^{\text {st }}$ storm. Table B.1 shows a record of the calibration runs in which the model parameters were modified in order to match the observed hydrograph. The table also shows a calculation of the watershed mass balance for each run. The mass balance components, computed as volume in $\mathrm{m}^{3}$, are as follows; Total precipitation $(\mathrm{P})$, total overland flow or runoff $(\mathrm{Q})$, compressible subsurface storage $(\mathrm{Sc})$, pore storage $(\mathrm{Sp})$, and surface storage (Ss). The mass balance is calculated as follow:

$\mathrm{P}-\mathrm{Q}=$ Total Storage $(\mathrm{Sc}+\mathrm{Sp}+\mathrm{Ss}) \rightarrow \mathrm{P}-\mathrm{Q}-\mathrm{Sc}-\mathrm{Sp}-\mathrm{Ss}=$ Error

(Equation 6) 
Table 3 summarizes the runs used to test the model's sensitivity to certain calibration parameters while Figures B.1 through B.10 show the corresponding effects in the simulated hydrograph. During runs without a subsurface layer assigned, the domain would saturate quickly, because of the very low porosity and hydraulic conductivity used to match the urbanization of the surface. This clearly affected the behavior of the simulated hydrograph at later times in the simulation (Figure B.1) because the total volume of outflow was overestimated as the water could not infiltrate into the already saturated domain. Once the subsurface was added and lower porosity and hydraulic conductivity were assigned beneath the surface layer(s), the model responded more readily to changes in field and channel parameters. The vertical grid size had a similar effect (Figure B.2) since smaller grid cells saturate faster. Figure B.2 shows the rising tail of the simulated hydrograph for run35 which has a grid size of 0.1 meters in the vertical. Run34, which has twice that vertical grid size, does not show this effect.

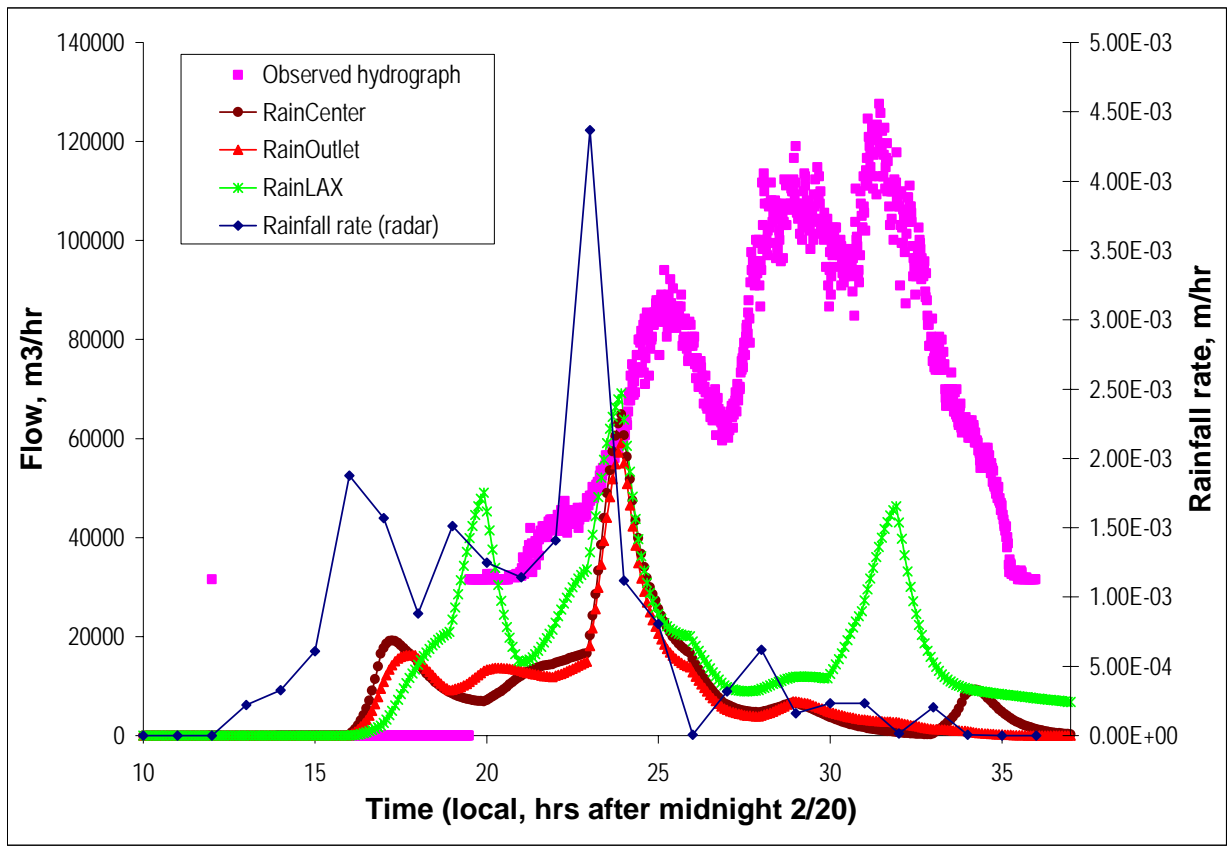

Figure (4): Radar and rain gage storm data along with the resulting observed hydrograph at DCW. 
Table (3): Summary of parameter sensitivity runs with reference to corresponding figures in Appendix B.

\begin{tabular}{|c|c|c|c|c|}
\hline \multirow{2}{*}{ Parameter } & \multicolumn{3}{|c|}{ Runs compared } & \multirow{2}{*}{ Figure } \\
\hline & Run & Imber (parameter $v$ & ue) & \\
\hline Subsurface added & $\begin{array}{c}\text { run21 } \\
\text { (without subsurface) }\end{array}$ & $\begin{array}{c}\text { run49 } \\
\text { (with subsurface) }\end{array}$ & $(-)$ & B.1 \\
\hline Vertical grid size, $\mathrm{dz}(\mathrm{m})$ & run35 $(0.1)$ & run34 (0.2) & $(-)$ & B.2 \\
\hline Channel Manning $\left(\mathrm{hr} / \mathrm{m}^{1 / 3}\right)$ & run70 (1.0E-7) & run72 (2.0E-7) & run71 (3.0E-7) & B.3 \\
\hline Field Manning $\left(\mathrm{hr} / \mathrm{m}^{1 / 3}\right)$ & run51 (1.0E-6) & run52 (5.0E-6) & run49 (2.0E-5) & B.4 \\
\hline Channel porosity & run70 (0.00009) & run69 $(0.0001)$ & $(-)$ & B.5 \\
\hline Field porosity & run30 $(0.001)$ & run31 (0.01) & $(-)$ & B. 6 \\
\hline Subsurface porosity & run57 (0.01) & run59 $(0.2)$ & $(-)$ & B.7 \\
\hline Field hydraulic conductivity (m/hr) & run55 $(0.0005)$ & run54 $(0.001)$ & run53 $(0.003)$ & B.8 \\
\hline Thickness of field layer & run54 (1 layer) & run57 (2 layers) & run65 (3 layers) & B.9 \\
\hline Field slopes & $\begin{array}{c}\text { run37 } \\
\left(0.5^{\star} \text { field slopes }\right)\end{array}$ & $\begin{array}{c}\text { run45 } \\
\left(0.25^{\star} \text { field slopes }\right)\end{array}$ & $\begin{array}{c}\text { run46 } \\
\left(0.05^{\star} \text { field slopes) }\right.\end{array}$ & B.10 \\
\hline
\end{tabular}

Changes in the field Manning's coefficient had a greater effect on the hydrograph and total runoff volume than changes in the channel Manning's coefficient as shown in figures B.3 and B.4. This is true, despite the fact that the range of variability in the channel Manning's coefficient was smaller than that for the field. It follows that the field friction has a higher effect on the total outflow as there are more cells assigned as field cells than assigned as channel cells. Thus, a much larger amount of rainfall runoff is affected by the field Manning's than the channel.

Not much sensitivity was observed in the case of the channel porosity, since this is originally assigned at a very low value (Figure B.5). Higher effects are noticed for changing the field and subsurface porosities as shown in figures B.6 and B.7. Furthermore, since the field hydraulic conductivity was assigned to low values due to the urbanization of the DCW, changing it had little effect on the hydrograph (Figure B.8).

One important factor in the model design was selecting the appropriate number of layers on the top of the domain to be assigned to the field and channel. These top layers would directly affect the process of runoff generation in the model since the top cells need to saturate before this occurs, and this process in turn is related to the rate of infiltration to the subsurface. This rate of infiltration depends on the vertical effective hydraulic conductivity. As more layers are assigned to the field, the vertical effective hydraulic conductivity becomes less and thus more surface runoff is generated. This effect is shown in Figure B.9 which shows that the total runoff volume is inversely related to the number of the field assigned layers.

Finally the sensitivity of the model to changing thye processed field slopes (from figure 3) is shown in Figure B.10 which shows a direct relationship between this and the total runoff volume. This is not unexpected since smaller slopes give the ponded water on the surface more time to infiltrate into the subsurface. 


\section{Results}

Table 4 shows the model parameters of the calibrated simulation run (run72). The hydraulic conductivity and porosity fields for this run are shown in Figures 5 and 6, respectively. This run has the three top layers assigned for the field and channel with much lower hydraulic conductivities and porosities than the subsurface. The total runoff volume was about $29 \%$ of the total precipitation volume.

Since the radar rainfall data was used in calibrating the model, the effect of rainfall spatial variability was tested by running this simulation (run

72) for the same storm event but with the rainfall data recorded at each of the three rainfall locations within DCW (at LAX, center, and outlet of the domain). Figure 7 shows the calibrated hydrograph for run72 (with radar rainfall data averaged over the domain), and the resulting hydrographs for the three individual rainfall rain gage data locations. These hydrographs provide an envelope of prediction that encompasses both the observed outflow and the simulation using the averaged rainfall observations. This demonstrates that the spacial variability in rainfall at locations around the DWC is greater than differences between calibration runs.
Table (4): Summary of calibrated run parameters.

\begin{tabular}{|c|c|}
\hline RUN NAME & run72 \\
\hline $\begin{array}{l}\text { Vertical Grid Size } \\
\text { Specific Storage } \\
\text { Change in Slopes }\end{array}$ & $\begin{array}{l}\mathrm{dz}=0.1,3 \text { cell field } \\
\mathrm{Ss}=1.0 \mathrm{E}-4 \\
\text { Half field slopes }\end{array}$ \\
\hline $\begin{array}{l}\text { Channel Ksat }(\mathrm{m} / \mathrm{hr}) \\
\text { Field Ksat }(\mathrm{m} / \mathrm{hr}) \\
\text { Subsurface Ksat }(\mathrm{m} / \mathrm{hr}) \\
\text { Channel Porosity } \\
\text { Field Porosity } \\
\text { Subsurface Porosity } \\
\text { Channel Manning's Coefficient }\left(\mathrm{hr} / \mathrm{m}^{1 / 3}\right) \\
\text { Field Manning's Coefficient }\left(\mathrm{hr} / \mathrm{m}^{1 / 3}\right)\end{array}$ & $\begin{array}{l}\text { K_chann }=0.0001 \\
\text { K_field }=0.001 \\
\text { K_subsurf }=0.05 \\
\text { por_chann }=0.00009 \\
\text { por_field }=0.003 \\
\text { por_subsurf }=0.01 \\
n \text { _chann }=2.0 \mathrm{E}-7 \\
\mathrm{n} \text { _field }=6.0 \mathrm{E}-6\end{array}$ \\
\hline $\begin{array}{l}\text { Precipitation }(\mathrm{P}) \\
\text { Runoff }(\mathrm{Q}) \\
\text { Compressible Storage (Sc) } \\
\text { Pore Storage (Sp) } \\
\text { Total (Sp+Sc) } \\
\text { Surface Storage (ponding) (Ss) }\end{array}$ & $\begin{array}{l}4.229 \mathrm{E}+06 \\
1.241 \mathrm{E}+06 \\
3.967 \mathrm{E}+04 \\
2.174 \mathrm{E}+06 \\
2.214 \mathrm{E}+06 \\
7.344 \mathrm{E}+05\end{array}$ \\
\hline $\begin{array}{l}\text { Error (P-Q-Ss-Sp-Sc) } \\
\text { Error (percent of P) } \\
\text { Q I P (\%) }\end{array}$ & $\begin{array}{l}3.994 \mathrm{E}+04 \\
0.9444 \\
29.3379\end{array}$ \\
\hline
\end{tabular}

Figure (5): Calibrated Saturated Hydraulic Conductivity Field in $\mathrm{m} / \mathrm{hr}$ (log scale) of Dominguez Channel watershed. 


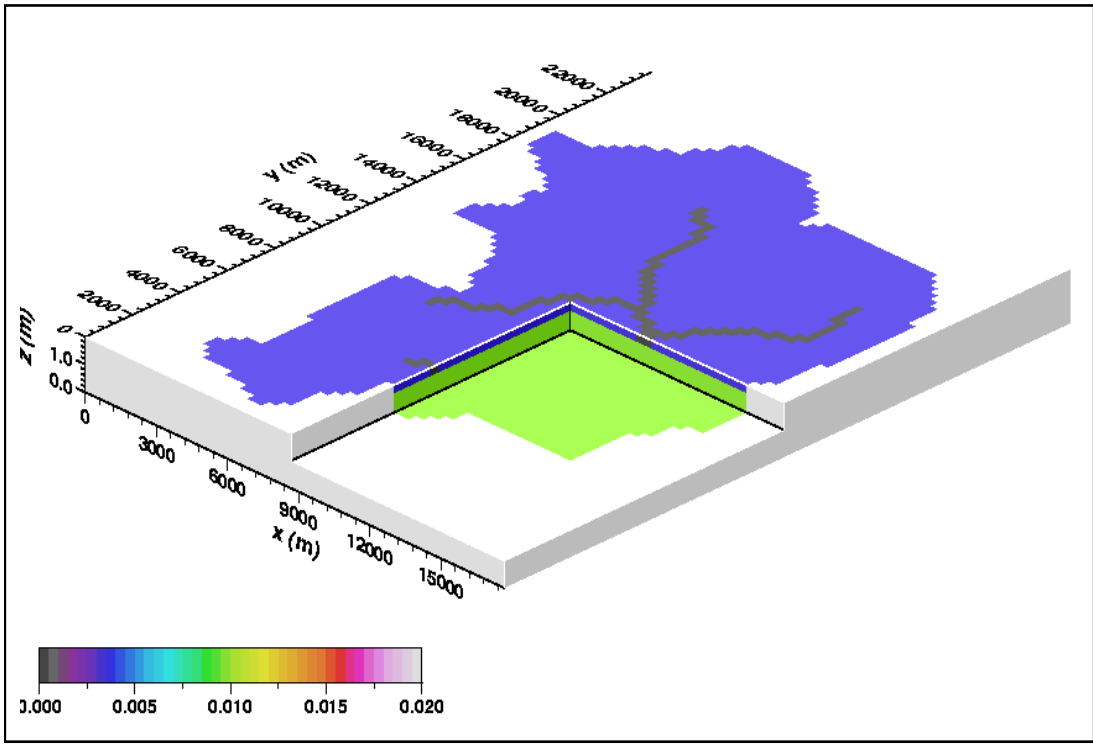

Figure (6): Calibrated Porosity Field of Dominguez Channel watershed

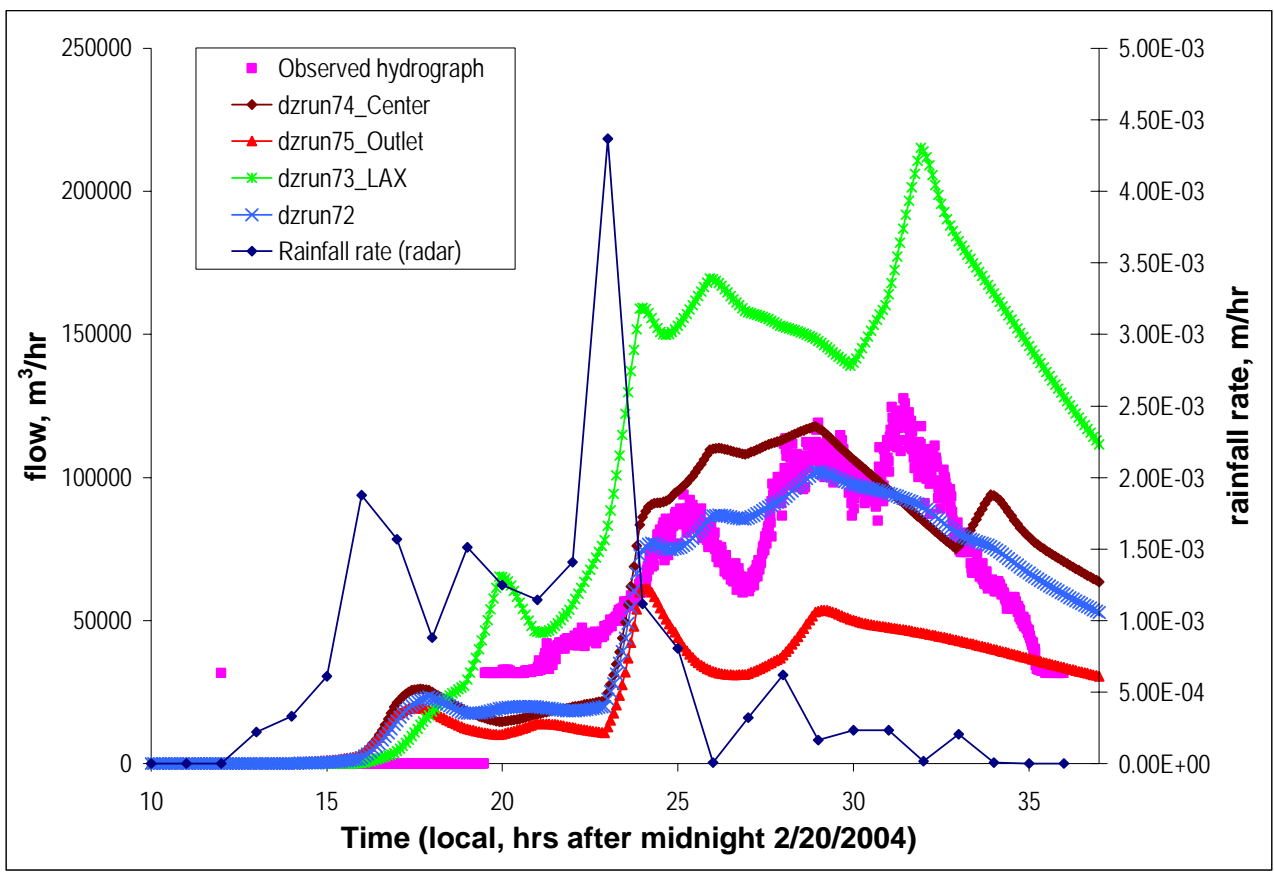

Figure (7): The calibrated hydrograph (run72) and runs with rain gage rainfall data for the same storm. 


\section{References:}

Anderson MP, Woessner WW (1992). “Applied groundwater modeling: Simulation of flow and advective transport”. San Diego: Academic Press, p. 281.

Ashby, S.F. and R.D. Falgout (1996). A parallel multigrid preconditioned conjugate gradient algorithm for groundwater flow simulations. Nuclear Science and Engineering, 124(1):145-59..

Jones J.E. and C.S. Woodward (2001), Newton-krylov-multigrid solvers for large-scale, highly heterogeneous, variably saturated flow problems. Advances in Water Resources, 24:763-774.

Kollet S.J. and RM Maxwell (2006) Integrated surface-groundwater flow modeling a freesurface overland flow boundary condition in a parallel groundwater flow model. Advances in Water Resources, 29(7): 945-958.

MEC Analytical Systems, Inc. (MEC). April 2004. Dominguez Watershed Management Master Plan, “An urban industrial watershed in balance with the environment”. Prepared for the Dominguez Watershed Advisory Council, County of Los Angeles Department of Public Works,

National Oceanic and Atmospheric Administration's National Weather Service (NWS);

NEXRAD Rainfall Radar data (http://dipper.nws.noaa.gov/hdsb/data/nexrad/nexrad.html).

Van Genuchten M. Th., (1980), “A closed-form equation for predicting the hydraulic conductivity of unsaturated soils”. Soil Science Society of America Journal, 44:892-898. 


\section{APPENDIX A: Dominguez Channel Watershed}

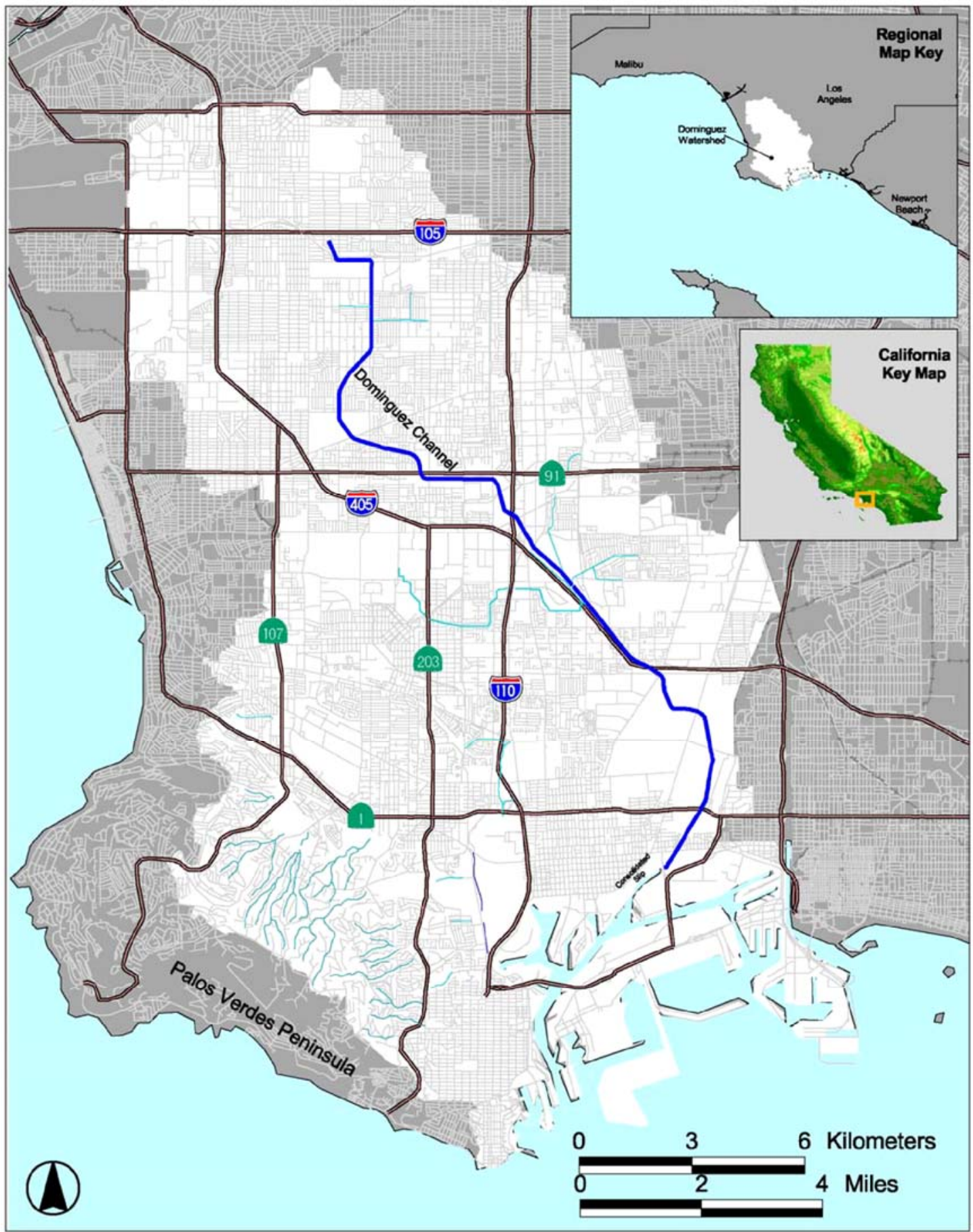

Figure A.1: Regional map showing the location of the Dominguez Channel Watershed (MEC, 2004). 


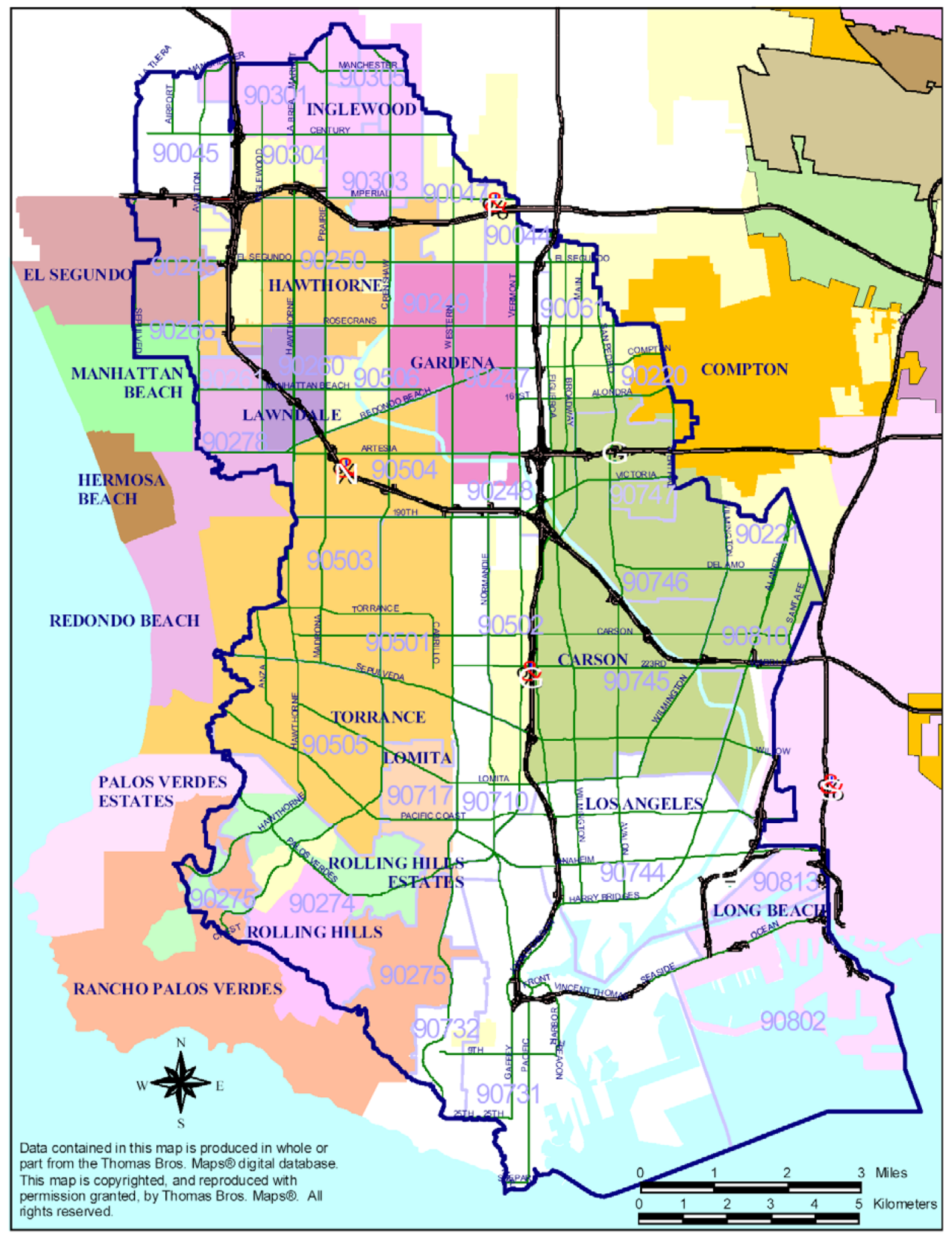

Figure A.2: Cities and zip codes within the Dominguez Watershed (MEC, 2004). 


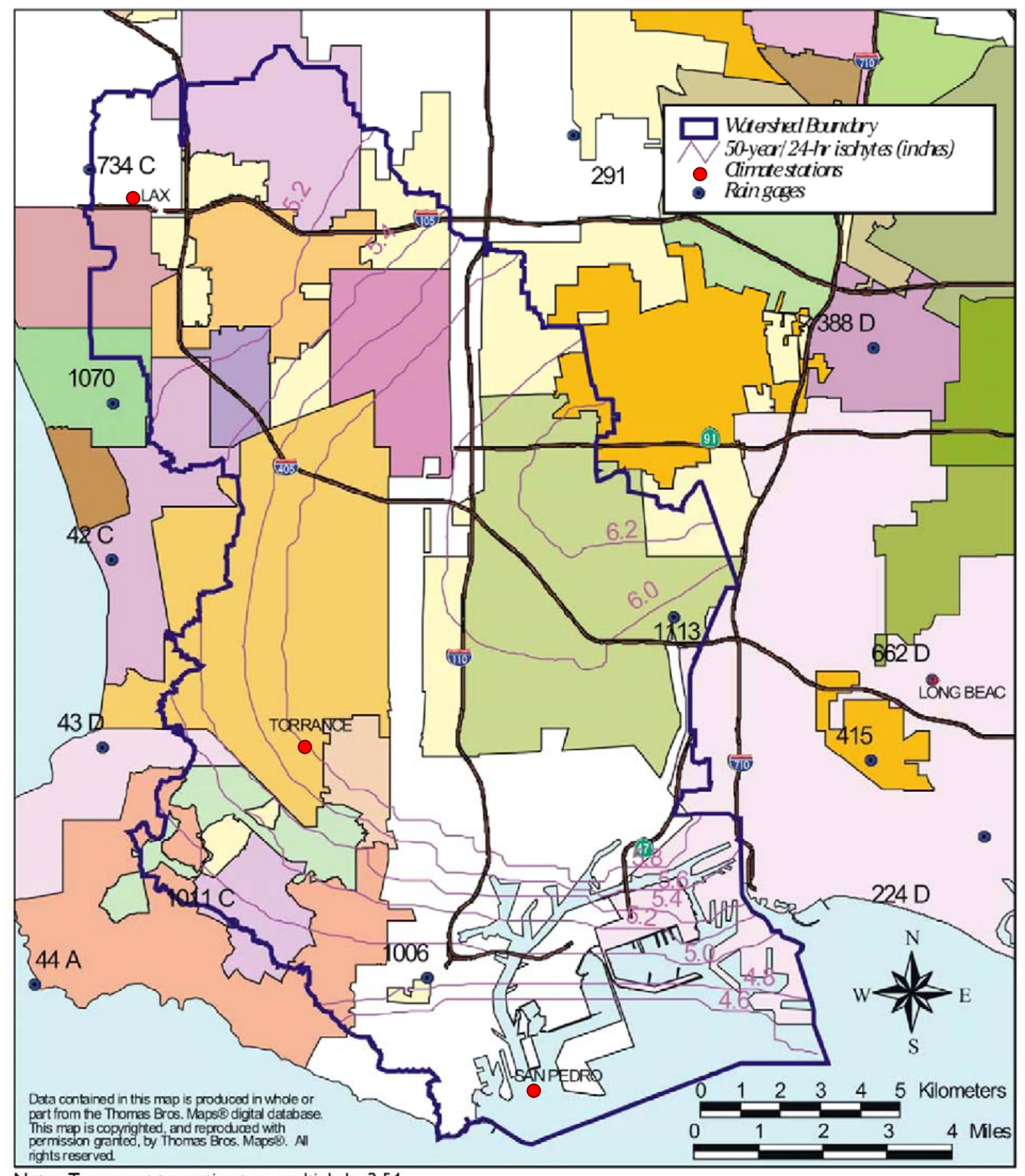

Note: To convert to centimeters, multiply by 2.54

Figure A.3: Isohyetal Map of precipitation (associated with a 50-year, 24-hour rainfall design storm) for the Dominguez Channel Watershed with locations of weather gages $(M E C, 2004)$. 


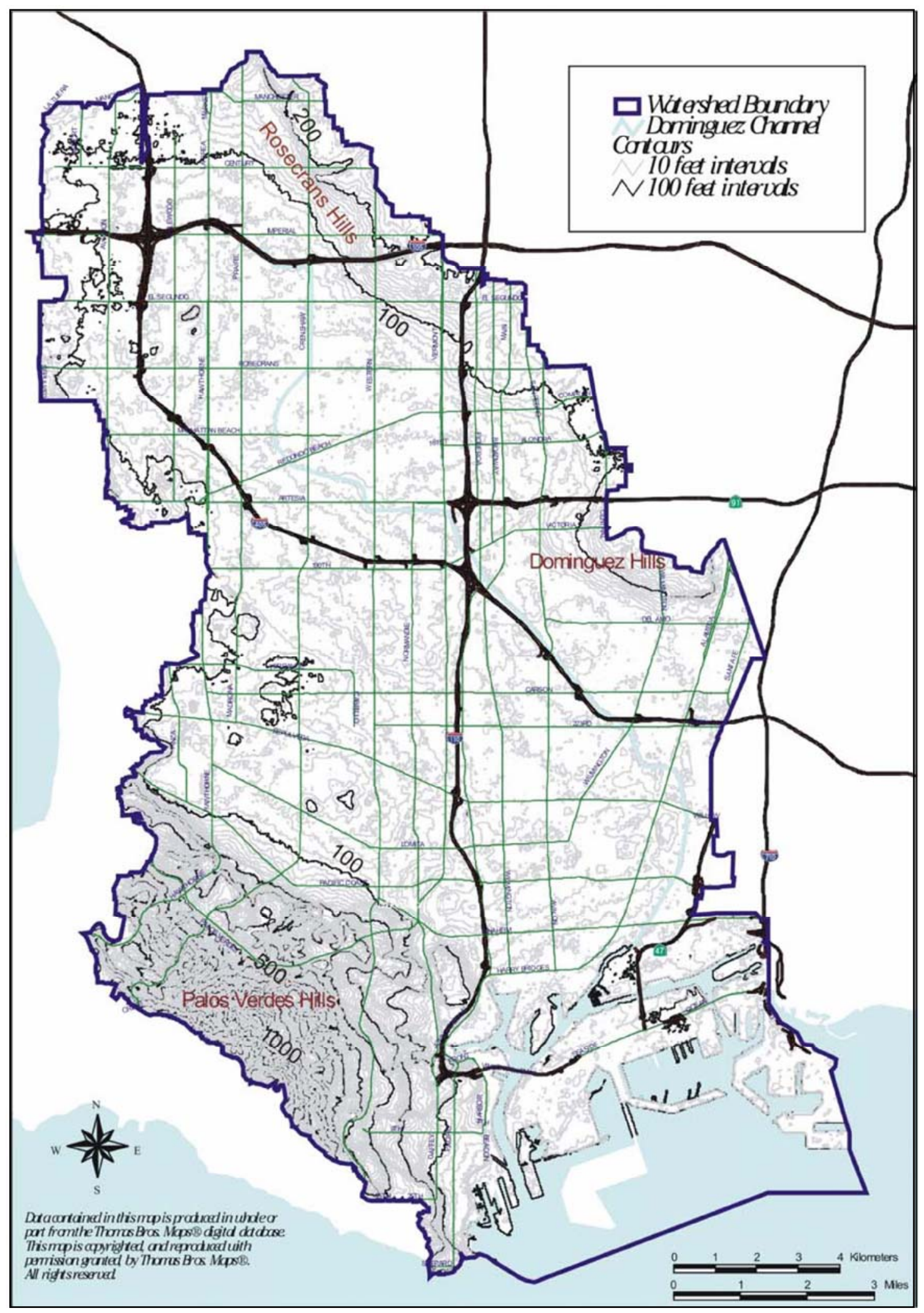

Figure A.4: Dominguez Channel Watershed topography (MEC, 2004). 


\section{APPENDIX B: Calibration Runs}

Table B.1: Record of calibration runs and mass balance calculations

\begin{tabular}{|c|c|c|c|c|c|}
\hline RUN NAME & run1 & run2 & run3 & run4 & run5 \\
\hline Rainfall Data & Radar Data & Radar Data & Radar Data & Radar Data & Radar Data \\
\hline Taken From Run & - & - & - & - & - \\
\hline Vertical Grid Size (dz), m & $d z=0.1$ & $d z=0.1$ & $d z=0.1$ & $d z=0.1$ & $d z=0.1$ \\
\hline Specific Storage (Ss), $\mathrm{m}^{-1}$ & $\mathrm{Ss}=1.0 \mathrm{E}-4$ & Ss $=1.0 \mathrm{E}-4$ & Ss $=1.0 \mathrm{E}-4$ & $S s=1.0 E-4$ & $S s=1.0 \mathrm{E}-4$ \\
\hline Change in Slopes (if any) & - & - & - & - & - \\
\hline Channel Ksat * (m/hr) & K_chann $=0.0001$ & K_chann $=0.0001$ & K_chann=0.00001 & K_chann $=0.00001$ & K_chann $=0.0001$ \\
\hline Field Ksat (m/hr) & $K \_$field $=0.1$ & $K \_$field $=0.1$ & K_field $=0.0001$ & K_field=0.001 & K_field $=0.001$ \\
\hline \multicolumn{6}{|l|}{ Subsurface Ksat (m/hr) } \\
\hline Channel Porosity & por_chann=0.0001 & por_chann $=0.0001$ & por_chann $=0.0001$ & por_chann=0.0001 & por_chann $=0.0001$ \\
\hline Field Porosity & por_field=0.1 & por_field $=0.1$ & por_field=0.001 & por_field=0.01 & por_field=0.001 \\
\hline \multicolumn{6}{|l|}{ Subsurface Porosity } \\
\hline Channel Manning's Coefficient $\left(\mathrm{hr} / \mathrm{m}^{1 / 3}\right)$ & n_chann=1.0E-6 & n_chann=7.0E-7 & n_chann=7.0E-7 & n_chann=1.0E-7 & n_chann=1.0E-6 \\
\hline Field Manning's Coefficient $\left(\mathrm{hr} / \mathrm{m}^{1 / 3}\right)$ & n_field=1.0E-5 & n_field=1.0E-6 & n_field=1.0E-6 & n_field=1.0E-6 & n_field=1.0E-5 \\
\hline Simulation Time Step & $\mathrm{dt}=5 \mathrm{mins}$ & $\mathrm{dt}=5 \mathrm{mins}$ & $\mathrm{dt}=5 \mathrm{mins}$ & $\mathrm{dt}=5 \mathrm{mins}$ & $\mathrm{dt}=5 \mathrm{mins}$ \\
\hline Precipitation (P), $\mathrm{m}^{3}$ & $4.229 E+06$ & $4.229 \mathrm{E}+06$ & $4.229 \mathrm{E}+06$ & $4.229 \mathrm{E}+06$ & $4.229 \mathrm{E}+06$ \\
\hline Runoff $(Q), \mathbf{m}^{3}$ & 2.537E+05 & $2.585 E+05$ & $3.730 E+06$ & 2.297E+05 & 2.297E+05 \\
\hline Compressible Storage (Sc), $\mathrm{m}^{3}$ & $2.777 \mathrm{E}+03$ & $2.776 \mathrm{E}+03$ & 4.073E+04 & 1.634E+04 & $1.634 \mathrm{E}+04$ \\
\hline Pore Storage (Sp), $\mathrm{m}^{3}$ & $3.929 E+06$ & $3.929 E+06$ & 2.463E+05 & $3.927 \mathrm{E}+06$ & $3.927 \mathrm{E}+06$ \\
\hline Total Subsurface Storage $(\mathrm{Sp}+\mathrm{Sc}), \mathrm{m}^{3}$ & $3.932 E+06$ & $3.932 E+06$ & $2.870 \mathrm{E}+05$ & $3.943 \mathrm{E}+06$ & $3.943 \mathrm{E}+06$ \\
\hline Surface Storage (ponding) (Ss), $\mathrm{m}^{3}$ & $1.666 \mathrm{E}+04$ & $1.181 \mathrm{E}+04$ & $1.716 \mathrm{E}+05$ & $1.041 \mathrm{E}+04$ & $1.041 \mathrm{E}+04$ \\
\hline Error (P-Q-Ss-Sp-Sc), $\mathrm{m}^{3}$ & $2.701 E+04$ & $2.700 E+04$ & $4.000 E+04$ & $4.586 \mathrm{E}+04$ & $4.586 \mathrm{E}+04$ \\
\hline Error (percent of P) & 0.6387 & 0.6384 & 0.9458 & 1.0843 & 1.0843 \\
\hline $\mathrm{Q} / \mathrm{P}(\%)$ & 5.9979 & 6.1130 & 88.2100 & 5.4313 & 5.4313 \\
\hline
\end{tabular}

* Ksat: Saturated hydraulic conductivity (m/hour) 
Table B.1 (Continued)

\begin{tabular}{|c|c|c|c|c|c|c|}
\hline run6 & run7 & run8 & run9 & run10 & run11 & run12 \\
\hline Radar Data & Radar Data & Radar Data & Radar Data & Radar Data & Radar Data & Radar Data \\
\hline- & - & - & - & - & - & - \\
\hline$d z=0.1$ & $d z=0.1$ & $d z=0.1$ & $\mathrm{dz}=0.1$ & $\mathrm{dz}=0.1$ & $\mathrm{dz}=0.1$ & $d z=0.1$ \\
\hline $\mathrm{Ss}=1.0 \mathrm{E}-4$ & $S s=1.0 \mathrm{E}-4$ & Ss $=1.0 \mathrm{E}-4$ & Ss $=1.0 \mathrm{E}-4$ & $S s=1.0 E-4$ & $S s=1.0 E-4$ & Ss $=1.0 \mathrm{E}-4$ \\
\hline- & - & Half field slopes & Half field slopes & Half field slopes & Half field slopes & 0.9 field slopes \\
\hline K_chann=0.0001 & K_chann $=0.0001$ & K_chann $=0.0001$ & \multirow{2}{*}{$\begin{array}{l}\text { K_chann }=0.0001 \\
K \_ \text {field }=0.1\end{array}$} & K_chann=0.0001 & K_chann $=0.0001$ & K_chann=0.0001 \\
\hline K_field $=0.001$ & K_field $=0.001$ & $K \_$field $=0.001$ & & $K \_$field $=0.001$ & K_field=0.001 & K_field $=0.001$ \\
\hline por_chann=0.0001 & por_chann $=0.0001$ & por_chann $=0.0001$ & \multirow{2}{*}{$\begin{array}{l}\text { por_chann=0.0001 } \\
\text { por_field }=0.1\end{array}$} & por_chann $=0.0001$ & por_chann $=0.0001$ & por_chann $=0.0001$ \\
\hline por_field=0.001 & por_field $=0.001$ & por_field $=0.001$ & & por_field $=0.001$ & por_field $=0.001$ & por_field=0.001 \\
\hline $\begin{array}{l}n \_ \text {chann=3.0E-6 } \\
n \_ \text {field }=5.0 E-5\end{array}$ & $\begin{array}{l}\text { n_chann=1.0E-6 } \\
n \_ \text {field }=1.0 E-5\end{array}$ & $\begin{array}{l}n \_ \text {chann=1.0E-6 } \\
n \_ \text {field }=1.0 E-5\end{array}$ & $\begin{array}{l}\text { n_chann=1.0E-7 } \\
\text { n_field }=1.0 E-6\end{array}$ & $\begin{array}{l}\text { n_chann=5.0E-7 } \\
n \_ \text {field }=5.0 E-6\end{array}$ & $\begin{array}{l}\text { n_chann=5.0E-6 } \\
n \_ \text {field }=5.0 E-5\end{array}$ & $\begin{array}{l}\text { n_chann=1.0E-6 } \\
n \_ \text {field }=1.0 E-5\end{array}$ \\
\hline $\mathrm{dt}=5 \mathrm{mins}$ & $\mathrm{dt}=5 \mathrm{mins}$ & $\mathrm{dt}=5 \mathrm{mins}$ & $d t=5 \mathrm{mins}$ & $\mathrm{dt}=5 \mathrm{mins}$ & $\mathrm{dt}=5 \mathrm{mins}$ & $\mathrm{dt}=5 \mathrm{mins}$ \\
\hline $4.229 E+06$ & $4.229 E+06$ & $4.229 E+06$ & $4.229 E+06$ & $4.229 E+06$ & $4.229 E+06$ & $4.229 E+06$ \\
\hline $9.105 E+05$ & $2.781 E+06$ & $2.449 E+06$ & $2.688 E+04$ & $3.126 \mathrm{E}+06$ & $5.812 E+05$ & $2.734 \mathrm{E}+06$ \\
\hline $4.285 E+04$ & $4.250 E+04$ & $4.256 E+04$ & $2.774 \mathrm{E}+03$ & $4.243 E+04$ & $4.291 \mathrm{E}+04$ & $4.251 \mathrm{E}+04$ \\
\hline $2.463 \mathrm{E}+05$ & $2.463 E+05$ & $2.463 E+05$ & $4.099 \mathrm{E}+04$ & $2.463 E+05$ & $2.463 \mathrm{E}+05$ & $2.463 E+05$ \\
\hline $2.891 E+05$ & $2.888 E+05$ & $2.888 \mathrm{E}+05$ & $4.376 \mathrm{E}+04$ & $2.887 \mathrm{E}+05$ & $2.892 E+05$ & $2.888 \mathrm{E}+05$ \\
\hline $2.988 E+06$ & 1.117E+06 & $1.448 \mathrm{E}+06$ & $1.605 E+03$ & $7.723 E+05$ & $3.318 \mathrm{E}+06$ & 1.164E+06 \\
\hline $4.178 E+04$ & $4.244 E+04$ & $4.278 E+04$ & $4.157 E+06$ & $4.180 E+04$ & 4.073E+04 & $4.253 E+04$ \\
\hline 0.9880 & 1.0036 & 1.0116 & 98.2917 & 0.9884 & 0.9631 & 1.0058 \\
\hline 21.5301 & 65.7531 & 57.9144 & 0.6356 & 73.9229 & 13.7432 & 64.6370 \\
\hline
\end{tabular}


Table B.1 (Continued)

\begin{tabular}{|c|c|c|c|c|c|c|}
\hline run13 & run14 & run15 & run16 & run17 & run18 & run19 \\
\hline Radar Data & Radar Data & Radar Data & Radar Data & Radar Data & Radar Data & Radar Data \\
\hline- & - & - & - & - & - & - \\
\hline$d z=0.1$ & $\mathrm{dz}=0.1$ & $d z=0.1$ & $d z=0.1$ & $d z=0.1$ & $d z=0.1$ & $\mathrm{dz}=0.1$ \\
\hline $\mathrm{Ss}=1.0 \mathrm{E}-4$ & $S s=1.0 E-4$ & $S s=1.0 \mathrm{E}-4$ & Ss $=1.0 \mathrm{E}-4$ & $S s=1.0 E-4$ & $S s=1.0 \mathrm{E}-4$ & $S s=1.0 \mathrm{E}-4$ \\
\hline 0.6 field slopes & Half field slopes & Half field slopes & Half field slopes & 0.6 field slopes & Half field slopes & Half field slopes \\
\hline K_chann=0.0001 & K_chann $=0.0001$ & K_chann $=0.0001$ & K_chann $=0.0001$ & K_chann $=0.0001$ & K_chann $=0.0001$ & K_chann $=0.0001$ \\
\hline K_field $=0.001$ & $K \_$field $=0.001$ & $K \_$field $=0.001$ & $K \_$field $=0.001$ & K_field=0.001 & $K \_$field $=0.001$ & $K \_$field $=0.001$ \\
\hline por_chann=0.0001 & por_chann $=0.0001$ & por_chann $=0.0001$ & por_chann $=0.0001$ & por_chann $=0.0001$ & por_chann $=0.0001$ & por_chann $=0.0001$ \\
\hline por_field $=0.001$ & por_field $=0.001$ & por_field $=0.001$ & por_field $=0.001$ & por_field $=0.001$ & por_field $=0.001$ & por_field $=0.001$ \\
\hline \multirow{3}{*}{$\begin{array}{l}\text { n_chann=1.0E-6 } \\
n \_f i e l d=1.0 E-5 \\
d t=5 \text { mins }\end{array}$} & n_chann=5.0E-6 & n_chann=1.0E-6 & n_chann=1.0E-6 & n_chann=1.0E-6 & n_chann=9.0E-7 & n_chann=1.0E-6 \\
\hline & \multirow{2}{*}{$\begin{array}{l}\text { n_field }=1.0 E-5 \\
d t=5 \text { mins }\end{array}$} & $n \_$field $=5.0 \mathrm{E}-5$ & $n \_$field $=4.0 E-5$ & $n \_$field=4.0E-5 & $n \_$field $=4.0 E-5$ & $n \_$field $=2.0 \mathrm{E}-5$ \\
\hline & & $\mathrm{dt}=5 \mathrm{mins}$ & $d t=5 \mathrm{mins}$ & $\mathrm{dt}=5 \mathrm{mins}$ & $\mathrm{dt}=5 \mathrm{mins}$ & $d t=5 \mathrm{mins}$ \\
\hline 4.229E+06 & 4.229E+06 & 4.229E+06 & $4.229 \mathrm{E}+06$ & $4.229 E+06$ & $4.229 \mathrm{E}+06$ & 4.229E+06 \\
\hline $5.082 E+06$ & $2.023 E+06$ & $8.320 E+05$ & $9.888 E+05$ & $1.062 E+06$ & $9.998 \mathrm{E}+05$ & $1.675 \mathrm{E}+06$ \\
\hline $4.254 \mathrm{E}+04$ & $4.265 E+04$ & $4.286 E+04$ & $4.283 E+04$ & $4.282 E+04$ & $4.283 E+04$ & $4.271 E+04$ \\
\hline $2.463 \mathrm{E}+05$ & $2.463 E+05$ & $2.463 E+05$ & $2.463 E+05$ & $2.463 E+05$ & $2.463 E+05$ & $2.463 E+05$ \\
\hline $2.888 E+05$ & $2.889 E+05$ & $2.891 \mathrm{E}+05$ & $2.891 \mathrm{E}+05$ & $2.891 \mathrm{E}+05$ & $2.891 \mathrm{E}+05$ & $2.890 \mathrm{E}+05$ \\
\hline $1.356 \mathrm{E}+06$ & $1.873 E+06$ & 3.067E+06 & $2.910 \mathrm{E}+06$ & $2.836 \mathrm{E}+06$ & $2.899 E+06$ & $2.222 \mathrm{E}+06$ \\
\hline$-2.498 E+06$ & $4.379 E+04$ & $4.085 E+04$ & 4.144E+04 & 4.162E+04 & 4.144E+04 & 4.284E+04 \\
\hline-59.0731 & 1.0356 & 0.9659 & 0.9798 & 0.9842 & 0.9799 & 1.0129 \\
\hline 120.1703 & 47.8340 & 19.6744 & 23.3807 & 25.1194 & 23.6408 & 39.6075 \\
\hline
\end{tabular}


Table B.1 (Continued)

\begin{tabular}{|c|c|c|c|c|c|c|}
\hline run20 & run21 & run21_BC & run22 & run23 & run24 & run25 \\
\hline Radar Data & Radar Data & Radar Data & Radar Data & Radar Data & Radar Data & Radar Data \\
\hline- & - & - & - & - & - & - \\
\hline$d z=0.1$ & $d z=0.1$ & $\mathrm{dz}=0.1$ & $\mathrm{dz}=0.1$ & $d z=0.1$ & $d z=0.1$ & $\mathrm{dz}=0.1$ \\
\hline Ss $=1.0 \mathrm{E}-4$ & $S s=1.0 E-4$ & $S s=1.0 E-4$ & $S s=1.0 \mathrm{E}-4$ & $S s=1.0 \mathrm{E}-4$ & $S s=1.0 E-4$ & $\mathrm{Ss}=1.0 \mathrm{E}-4$ \\
\hline Half field slopes & Half field slopes & Half field slopes & Half field slopes & Half field slopes & Half field slopes & Half field slopes \\
\hline K_chann $=0.0001$ & K_chann $=0.0001$ & K_chann $=0.0001$ & K_chann $=0.0001$ & K_chann $=0.0001$ & K_chann $=0.0001$ & K_chann $=0.0001$ \\
\hline$K \_$field $=0.01$ & K_field $=0.003$ & K_field $=0.003$ & K_field $=0.03$ & K_field $=0.03$ & K_field $=0.03$ & K_field $=0.03$ \\
\hline por_chann=0.0001 & por_chann $=0.0001$ & por_chann=0.0001 & por_chann $=0.0001$ & por_chann $=0.0001$ & por_chann $=0.0001$ & por_chann=0.0005 \\
\hline por_field $=0.01$ & por_field=0.003 & por_field=0.003 & por_field=0.003 & por_field=0.005 & por_field $=0.001$ & por_field $=0.001$ \\
\hline n_chann=1.0E-6 & n_chann=1.0E-6 & n_chann=1.0E-6 & n_chann=1.0E- 6 & n_chann=1.0E-6 & n_chann=1.0E-6 & n_chann=1.0E-6 \\
\hline$n \_$field $=2.0 E-5$ & n_field=2.0E-5 & n_field=2.0E-5 & $n \_$field $=2.0 E-5$ & n_field=2.0E-5 & n_field=2.0E-5 & n_field=2.0E-5 \\
\hline$d t=5 \mathrm{mins}$ & $\mathrm{dt}=5 \mathrm{mins}$ & $\mathrm{dt}=5 \mathrm{mins}$ & $\mathrm{dt}=5 \mathrm{mins}$ & $\mathrm{dt}=5 \mathrm{mins}$ & $\mathrm{dt}=5 \mathrm{mins}$ & $\mathrm{dt}=5 \mathrm{mins}$ \\
\hline $4.229 E+06$ & 4.229E+06 & $4.229 E+06$ & $4.229 \mathrm{E}+06$ & $4.229 \mathrm{E}+06$ & $4.229 E+06$ & 4.229E+06 \\
\hline 4.617E+05 & $1.329 \mathrm{E}+06$ & $2.323 \mathrm{E}+05$ & $1.329 \mathrm{E}+06$ & $1.021 \mathrm{E}+06$ & $1.675 E+06$ & $1.668 \mathrm{E}+06$ \\
\hline $4.251 E+04$ & $4.268 E+04$ & 9.548E-01 & $4.268 E+04$ & $4.264 \mathrm{E}+04$ & $4.270 \mathrm{E}+04$ & 4.270E+04 \\
\hline $2.447 \mathrm{E}+06$ & $7.354 \mathrm{E}+05$ & $3.345 E+05$ & $7.354 \mathrm{E}+05$ & $1.225 \mathrm{E}+06$ & $2.463 E+05$ & $2.531 E+05$ \\
\hline $2.490 \mathrm{E}+06$ & $7.780 \mathrm{E}+05$ & $3.345 E+05$ & $7.780 \mathrm{E}+05$ & 1.267E+06 & $2.890 \mathrm{E}+05$ & $2.958 \mathrm{E}+05$ \\
\hline $1.238 E+06$ & $2.080 E+06$ & $9.485 E+03$ & $2.080 E+06$ & $1.899 \mathrm{E}+06$ & $2.222 \mathrm{E}+06$ & $2.222 \mathrm{E}+06$ \\
\hline 3.917E+04 & $4.218 E+04$ & $3.653 E+06$ & $4.216 E+04$ & $4.136 E+04$ & $4.282 E+04$ & $4.286 \mathrm{E}+04$ \\
\hline 0.9261 & 0.9973 & 86.3747 & 0.9968 & 0.9780 & 1.0125 & 1.0134 \\
\hline 10.9179 & 31.4282 & 5.4921 & 31.4282 & 24.1499 & 39.6075 & 39.4443 \\
\hline
\end{tabular}


Table B.1 (Continued)

\begin{tabular}{|c|c|c|c|c|c|c|}
\hline run26 & run27 & run28 & run29 & run30 & run31 & run32 \\
\hline $\begin{array}{c}\text { Radar Data } \\
-\end{array}$ & $\begin{array}{c}\text { Radar Data } \\
-\end{array}$ & $\begin{array}{c}\text { Radar Data } \\
-\end{array}$ & $\begin{array}{l}\text { Radar Data } \\
\text { from } 28\end{array}$ & $\begin{array}{l}\text { Radar Data } \\
\text { from } 26\end{array}$ & $\begin{array}{l}\text { Radar Data } \\
\text { from } 30\end{array}$ & $\begin{array}{l}\text { Radar Data } \\
\text { from } 31\end{array}$ \\
\hline$d z=0.1$ & $\mathrm{dz}=0.1$ & $d z=0.1$ & $d z=0.1$ & $\mathrm{dz}=0.2$ & $\mathrm{dz}=0.2$ & $\mathrm{dz}=0.2$ \\
\hline $\mathrm{Ss}=1.0 \mathrm{E}-4$ & $S s=2.0 E-4$ & $S s=1.0 \mathrm{E}-5$ & Ss $=1.0 \mathrm{E}-5$ & $S s=1.0 E-4$ & $S s=1.0 \mathrm{E}-4$ & $S s=1.0 \mathrm{E}-4$ \\
\hline Half field slopes & Half field slopes & Half field slopes & Half field slopes & Half field slopes & Half field slopes & Half field slopes \\
\hline K_chann=0.001 & K_chann=0.001 & K_chann $=0.001$ & K_chann=0.001 & K_chann=0.001 & K_chann=0.001 & K_chann $=0.001$ \\
\hline$K \_$field $=0.03$ & $K \_$field $=0.03$ & K_field $=0.03$ & $K \_$field $=0.03$ & K_field $=0.03$ & K_field $=0.03$ & K_field $=0.03$ \\
\hline por_chann $=0.0001$ & por_chann $=0.0001$ & por_chann $=0.0001$ & por_chann $=0.0001$ & por_chann $=0.0001$ & por_chann $=0.0001$ & por_chann $=0.0001$ \\
\hline por_field=0.001 & por_field $=0.001$ & por_field $=0.001$ & por_field $=0.001$ & por_field=0.001 & por_field=0.01 & por_field=0.01 \\
\hline n_chann=1.0E-6 & n_chann=1.0E-6 & n_chann=1.0E-6 & n_chann=1.0E-6 & n_chann=1.0E-6 & n_chann=1.0E-6 & n_chann=1.0E-7 \\
\hline$n \_$field=2.0E-5 & $n \_$field $=2.0 \mathrm{E}-5$ & $n \_$field=2.0E-5 & $n \_$field $=2.0 \mathrm{E}-5$ & $n \_$field=2.0E-5 & $n \_$field=2.0E-5 & $n \_$field=2.0E-5 \\
\hline $\mathrm{dt}=5 \mathrm{mins}$ & $d t=5 \mathrm{mins}$ & $\mathrm{dt}=5 \mathrm{mins}$ & $\mathrm{dt}=5 \mathrm{mins}$ & $\mathrm{dt}=5 \mathrm{mins}$ & $d t=5 \mathrm{mins}$ & $d t=5 \mathrm{mins}$ \\
\hline $4.229 E+06$ & 4.229E+06 & 4.229E+06 & $4.229 \mathrm{E}+06$ & $4.229 E+06$ & $4.229 \mathrm{E}+06$ & 4.229E+06 \\
\hline $1.675 \mathrm{E}+06$ & $1.632 \mathrm{E}+06$ & $1.714 \mathrm{E}+06$ & 1.737E+06 & $1.334 \mathrm{E}+06$ & $2.409 \mathrm{E}+05$ & $2.560 \mathrm{E}+05$ \\
\hline 4.270E+04 & $8.540 E+04$ & 4.270E+03 & $4.271 E+03$ & $1.699 \mathrm{E}+05$ & $5.625 \mathrm{E}+04$ & $5.624 \mathrm{E}+04$ \\
\hline $2.463 E+05$ & $2.463 E+05$ & $2.463 E+05$ & $2.155 E+05$ & $5.622 \mathrm{E}+05$ & $3.852 E+06$ & $3.852 E+06$ \\
\hline $2.890 E+05$ & $3.317 E+05$ & $2.506 E+05$ & $2.198 E+05$ & $7.321 E+05$ & $3.908 \mathrm{E}+06$ & $3.908 E+06$ \\
\hline $2.222 E+06$ & $2.208 E+06$ & $2.234 \mathrm{E}+06$ & $2.242 E+06$ & $2.088 E+06$ & $1.665 E+04$ & 1.597E+03 \\
\hline 4.282E+04 & $5.722 E+04$ & $3.005 E+04$ & $3.043 E+04$ & $7.503 E+04$ & $6.321 E+04$ & $6.314 \mathrm{E}+04$ \\
\hline 1.0125 & 1.3531 & 0.7106 & 0.7195 & 1.7742 & 1.4947 & 1.4930 \\
\hline 39.6075 & 38.5883 & 40.5297 & 41.0688 & 31.5394 & 5.6961 & 6.0539 \\
\hline
\end{tabular}


Table B.1 (Continued)

\begin{tabular}{|c|c|c|c|c|c|c|}
\hline run33 & run34 & run35 & run36 & run37 & run38 & run39 \\
\hline \multirow[t]{2}{*}{ Radar Data } & Radar Data & \multirow[t]{2}{*}{ Radar Data } & Radar Data & Radar Data & Radar Data & Radar Data \\
\hline & $\begin{array}{l}\text { SUBSURFACE } \\
\text { ADDED }\end{array}$ & & from 34 & from 34 & from 36 & from 38 \\
\hline$d z=0.2$ & $d z=0.2$ & $d z=0.1$ & $\mathrm{dz}=0.2$ & $\mathrm{dz}=0.2$ & $\mathrm{dz}=0.2$ & $\mathrm{dz}=0.2$ \\
\hline $\mathrm{Ss}=1.0 \mathrm{E}-4$ & $\mathrm{Ss}=1.0 \mathrm{E}-4$ & $S s=1.0 \mathrm{E}-4$ & $\mathrm{Ss}=1.0 \mathrm{E}-4$ & $\mathrm{Ss}=1.0 \mathrm{E}-4$ & $\mathrm{Ss}=1.0 \mathrm{E}-4$ & Ss $=1.0 \mathrm{E}-4$ \\
\hline Half field slopes & Half field slopes & Half field slopes & Half field slopes & Half field slopes & Half field slopes & $\begin{array}{l}0.1 \text { field \& channel } \\
\text { slopes }\end{array}$ \\
\hline K_chann $=0.001$ & K_chann $=0.0001$ & K_chann $=0.0001$ & K_chann $=0.0001$ & K_chann $=0.0001$ & K_chann $=0.0001$ & K_chann $=0.0001$ \\
\hline$K \_$field $=0.03$ & K_field=0.009 & K_field=0.009 & K_field=0.001 & K_field $=0.0001$ & K_field=0.001 & K_field=0.001 \\
\hline por_chann $=0.0001$ & $\begin{array}{l}\text { K_subsurf }=0.05 \\
\text { por_chann }=0.0001\end{array}$ & $\begin{array}{l}\text { K_subsurf }=0.05 \\
\text { por_chann }=0.0001\end{array}$ & $\begin{array}{l}\text { K_subsurf }=0.05 \\
\text { por_chann }=0.0001\end{array}$ & $\begin{array}{l}\text { K_subsurf }=0.05 \\
\text { por_chann }=0.0001\end{array}$ & $\begin{array}{l}\text { K_subsurf }=0.1 \\
\text { por_chann }=0.0001\end{array}$ & $\begin{array}{l}\text { K_subsurf }=0.1 \\
\text { por_chann }=0.0001\end{array}$ \\
\hline por_field $=0.01$ & por_field=0.001 & por_field=0.001 & por_field=0.001 & por_field=0.001 & por_field=0.005 & por_field $=0.005$ \\
\hline & por_subsurf $=0.01$ & por_subsurf=0.01 & por_subsurf $=0.01$ & por_subsurf $=0.01$ & por_subsurf $=0.01$ & por_subsurf=0.01 \\
\hline n_chann=1.0E-7 & n_chann=1.0E-7 & n_chann=1.0E-7 & n_chann=1.0E-7 & n_chann=1.0E-7 & n_chann=1.0E-7 & n_chann=1.0E-7 \\
\hline n_field $=6.0 \mathrm{E}-5$ & $n \_$field=2.0E-5 & n_field=2.0E-5 & n_field=2.0E-5 & $n \_$field $=2.0 \mathrm{E}-5$ & $n \_$field=2.0E-5 & n_field=2.0E-5 \\
\hline$d t=5 \mathrm{mins}$ & $d t=5 \mathrm{mins}$ & $\mathrm{dt}=5 \mathrm{mins}$ & $\mathrm{dt}=5 \mathrm{mins}$ & $d t=5 \mathrm{mins}$ & $\mathrm{dt}=5 \mathrm{mins}$ & $d t=5 \mathrm{mins}$ \\
\hline $4.229 E+06$ & $4.229 E+06$ & $4.229 E+06$ & $4.229 E+06$ & $4.229 E+06$ & $4.229 E+06$ & $4.229 E+06$ \\
\hline $2.560 E+05$ & $1.522 \mathrm{E}+05$ & 4.370E+05 & $1.525 E+05$ & $7.898 E+05$ & $1.446 \mathrm{E}+05$ & 1.390E+05 \\
\hline $5.624 \mathrm{E}+04$ & $5.409 E+04$ & $4.251 \mathrm{E}+04$ & $5.379 \mathrm{E}+04$ & $1.432 \mathrm{E}+03$ & $5.486 \mathrm{E}+04$ & $5.492 \mathrm{E}+04$ \\
\hline $3.852 E+06$ & $3.961 \mathrm{E}+06$ & $2.607 \mathrm{E}+06$ & $3.960 \mathrm{E}+06$ & $2.589 \mathrm{E}+06$ & $3.967 E+06$ & $3.973 E+06$ \\
\hline $3.908 E+06$ & $4.015 E+06$ & $2.649 E+06$ & 4.014E+06 & $2.591 E+06$ & $4.022 E+06$ & $4.028 \mathrm{E}+06$ \\
\hline $1.597 \mathrm{E}+03$ & $0.000 E+00$ & $1.241 \mathrm{E}+06$ & $0.000 E+00$ & $7.904 \mathrm{E}+05$ & $0.000 E+00$ & $0.000 E+00$ \\
\hline $6.314 \mathrm{E}+04$ & $6.218 E+04$ & $-9.746 E+04$ & $6.237 E+04$ & $5.826 E+04$ & $6.230 E+04$ & $6.230 E+04$ \\
\hline 1.4930 & 1.4703 & -2.3047 & 1.4747 & 1.3776 & 1.4732 & 1.4731 \\
\hline 6.0539 & 3.5997 & 10.3322 & 3.6070 & 18.6753 & 3.4202 & 3.2864 \\
\hline
\end{tabular}


Table B.1 (Continued)

\begin{tabular}{|c|c|c|c|c|c|}
\hline run40 & run41 & run42 & run43 & run44 & run45 \\
\hline $\begin{array}{l}\text { Radar Data } \\
\text { from } 39 \\
d z=0.2 \\
S s=10 F-4\end{array}$ & $\begin{array}{l}\text { Radar Data } \\
\text { from } 39 \\
\mathrm{dz}=0.2 \\
\mathrm{Ss}=10 \mathrm{~F}-4\end{array}$ & $\begin{array}{l}\text { Radar Data } \\
\text { from } 39 \\
\mathrm{dz}=0.2 \\
\mathrm{Ss}=1.0 \mathrm{~F}-4\end{array}$ & $\begin{array}{l}\text { Radar Data } \\
\text { from } 40 \\
\mathrm{dz}=0.2 \\
\mathrm{Ss}=1.0 \mathrm{~F}-4\end{array}$ & $\begin{array}{l}\text { Radar Data } \\
\text { from } 42 \\
d z=0.2 \\
S s=10 F-4\end{array}$ & $\begin{array}{l}\text { Radar Data } \\
\text { from } 37 \\
d z=0.2 \\
S s=1\end{array}$ \\
\hline $\begin{array}{l}\text { Ss=1.0E-4 } \\
0.1 \text { field \& channel } \\
\text { slopes }\end{array}$ & $\begin{array}{l}\text { Ss=1.0E-4 } \\
0.1 \text { field \& channel } \\
\text { slopes }\end{array}$ & $\begin{array}{l}\text { Ss=1.0E-4 } \\
0.1 \text { field \& channel } \\
\text { slopes }\end{array}$ & $\begin{array}{l}\text { SS=1.0E-4 } \\
0.1 \text { field \& channel } \\
\text { slopes }\end{array}$ & Half field slopes & 0.25 field slopes \\
\hline K_chann=0.0001 & K_chann $=0.0001$ & K_chann $=0.0001$ & K_chann $=0.0001$ & K_chann=0.0001 & K_chann=0.0001 \\
\hline K_field=0.001 & K_field=0.001 & K_field $=0.001$ & K_field=0.0001 & K_field=0.001 & $K \_$field $=0.0001$ \\
\hline K_subsurf=0.1 & K_subsurf $=0.1$ & K_subsurf=0.1 & K_subsurf $=0.1$ & K_subsurf=0.1 & K_subsurf=0.05 \\
\hline $\begin{array}{l}\text { por_chann=0.0001 } \\
\text { por_field }=0.005 \\
\text { por_subsurf }=0.01\end{array}$ & $\begin{array}{l}\text { por_chann=0.0001 } \\
\text { por_field }=0.005 \\
\text { por_subsurf }=0.01\end{array}$ & $\begin{array}{l}\text { por_chann=0.0001 } \\
\text { por_field=0.005 } \\
\text { por_subsurf }=0.01\end{array}$ & $\begin{array}{l}\text { por_chann }=0.0001 \\
\text { por_field }=0.005 \\
\text { por_subsurf }=0.01\end{array}$ & $\begin{array}{l}\text { por_chann=0.0001 } \\
\text { por_field }=0.005 \\
\text { por_subsurf }=0.01\end{array}$ & $\begin{array}{l}\text { por_chann }=0.0001 \\
\text { por_field }=0.001 \\
\text { por_subsurf }=0.01\end{array}$ \\
\hline n_chann=1.0E-6 & n_chann=1.0E-7 & n_chann=1.0E-6 & n_chann=1.0E-6 & n_chann=1.0E-6 & n_chann=1.0E-7 \\
\hline$n \_$field $=2.0 \mathrm{E}-5$ & n_field=1.0E-4 & $n \_$field $=5.0 \mathrm{E}-6$ & $n \_$field=2.0E-5 & $\mathrm{n} \_$field $=5.0 \mathrm{E}-6$ & $n \_$field=2.0E-5 \\
\hline $\mathrm{dt}=5 \mathrm{mins}$ & $\mathrm{dt}=5 \mathrm{mins}$ & $\mathrm{dt}=5 \mathrm{mins}$ & $\mathrm{dt}=5 \mathrm{mins}$ & $\mathrm{dt}=5 \mathrm{mins}$ & $\mathrm{dt}=5 \mathrm{mins}$ \\
\hline $4.229 \mathrm{E}+06$ & $4.229 \mathrm{E}+06$ & $4.229 \mathrm{E}+06$ & $4.229 E+06$ & $4.229 \mathrm{E}+06$ & 4.229E+06 \\
\hline $9.461 E+04$ & $1.390 E+05$ & 9.467E+04 & 9.467E+04 & $1.203 E+05$ & $5.968 E+05$ \\
\hline 5.517E+04 & $5.492 E+04$ & 5.517E+04 & 5.517E+04 & $5.508 \mathrm{E}+04$ & $1.444 \mathrm{E}+03$ \\
\hline $4.007 \mathrm{E}+06$ & $3.973 E+06$ & 4.007E+06 & 4.007E+06 & $3.991 E+06$ & 2.611E+06 \\
\hline $4.062 E+06$ & $4.028 \mathrm{E}+06$ & $4.062 E+06$ & $4.062 E+06$ & $4.046 \mathrm{E}+06$ & $2.612 E+06$ \\
\hline $1.008 E+04$ & $0.000 E+00$ & $1.009 E+04$ & $1.009 E+04$ & $1.112 \mathrm{E}+02$ & $9.617 \mathrm{E}+05$ \\
\hline $6.254 \mathrm{E}+04$ & $6.232 E+04$ & 6.257E+04 & 6.257E+04 & $6.237 E+04$ & $5.814 \mathrm{E}+04$ \\
\hline 1.4788 & 1.4736 & 1.4795 & 1.4795 & 1.4749 & 1.3747 \\
\hline 2.2371 & 3.2859 & 2.2386 & 2.2386 & 2.8456 & 14.1109 \\
\hline
\end{tabular}


Table B.1 (Continued)

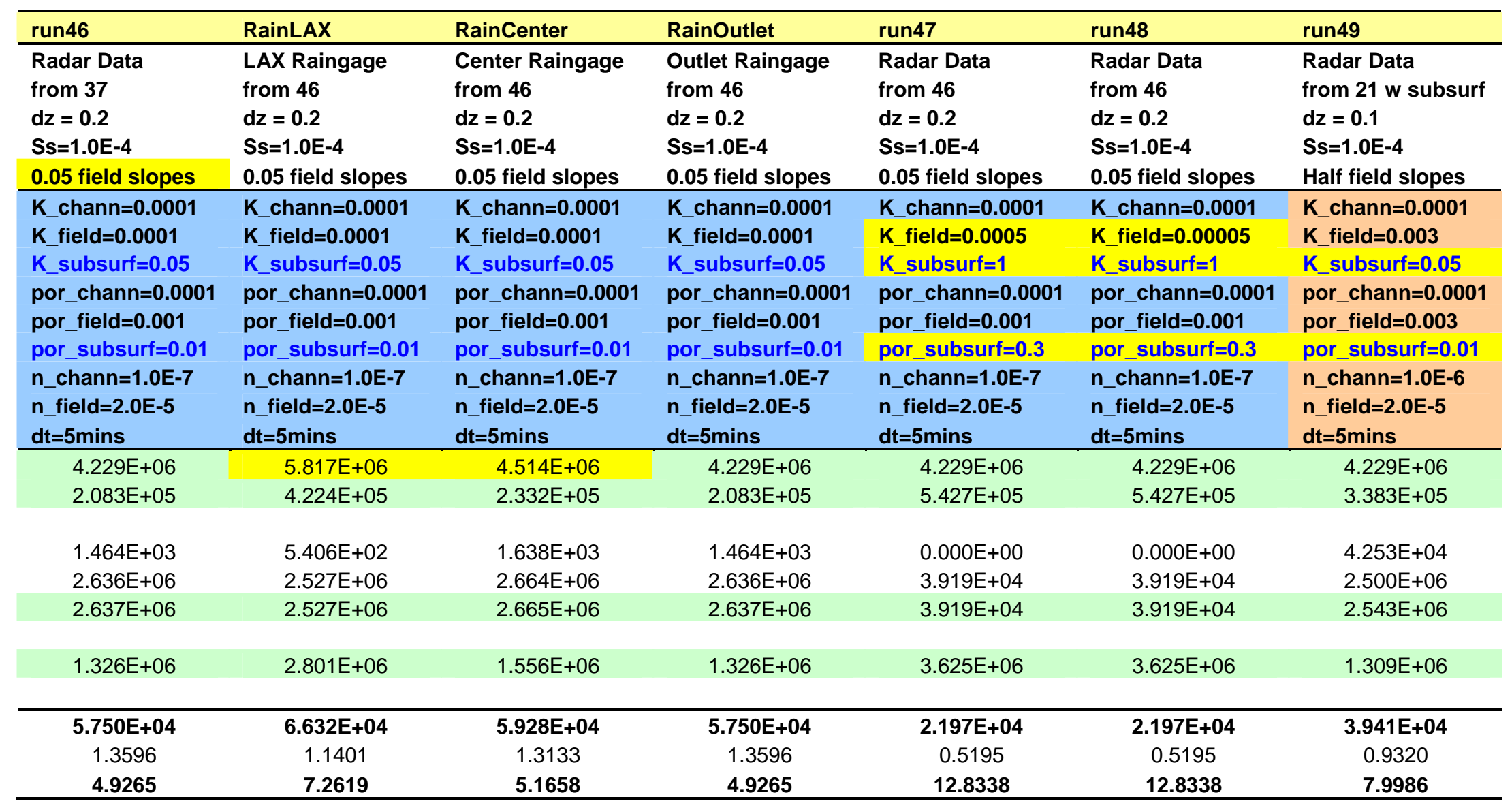


Table B.1 (Continued)

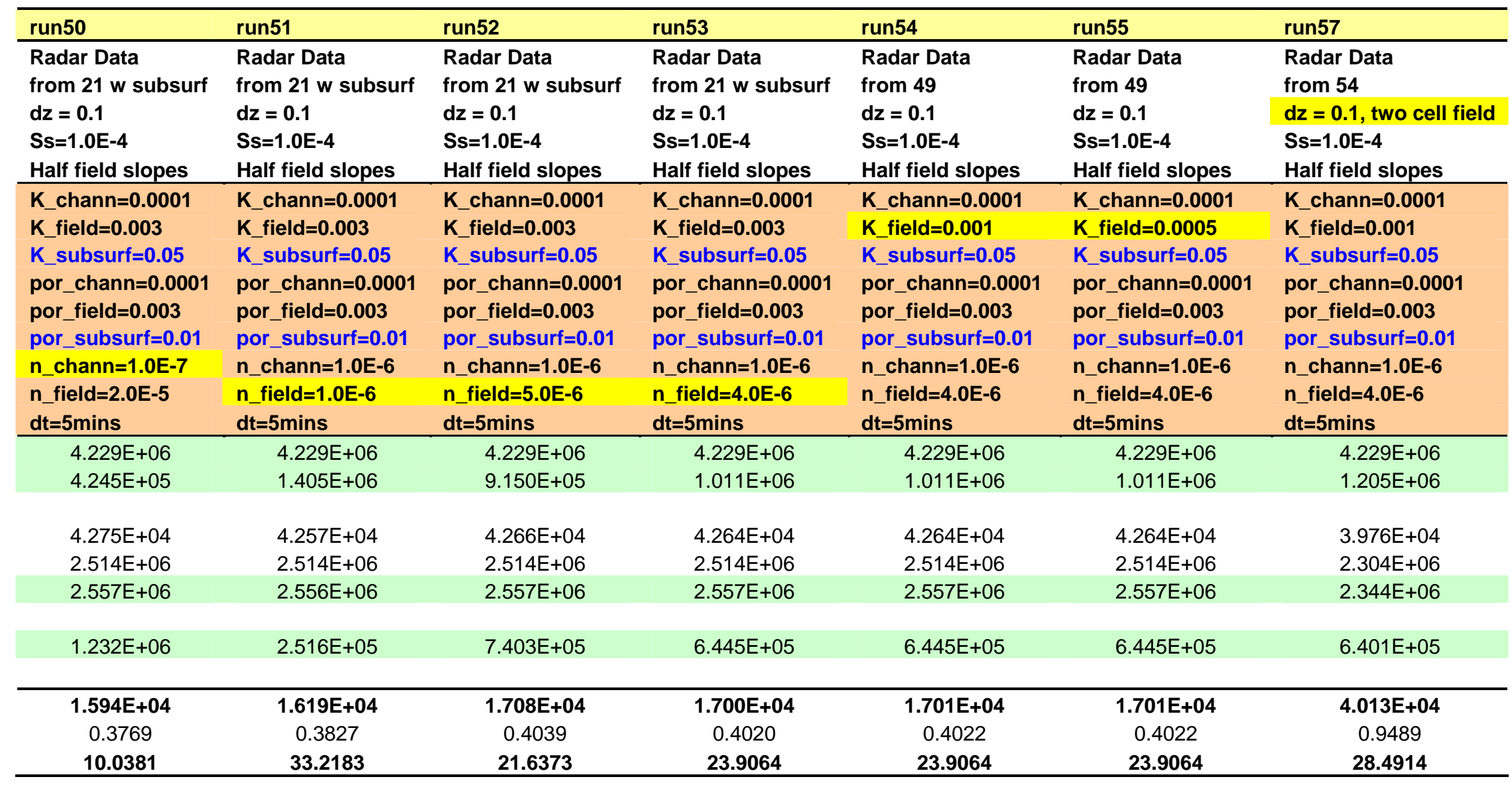


Table B.1 (Continued)

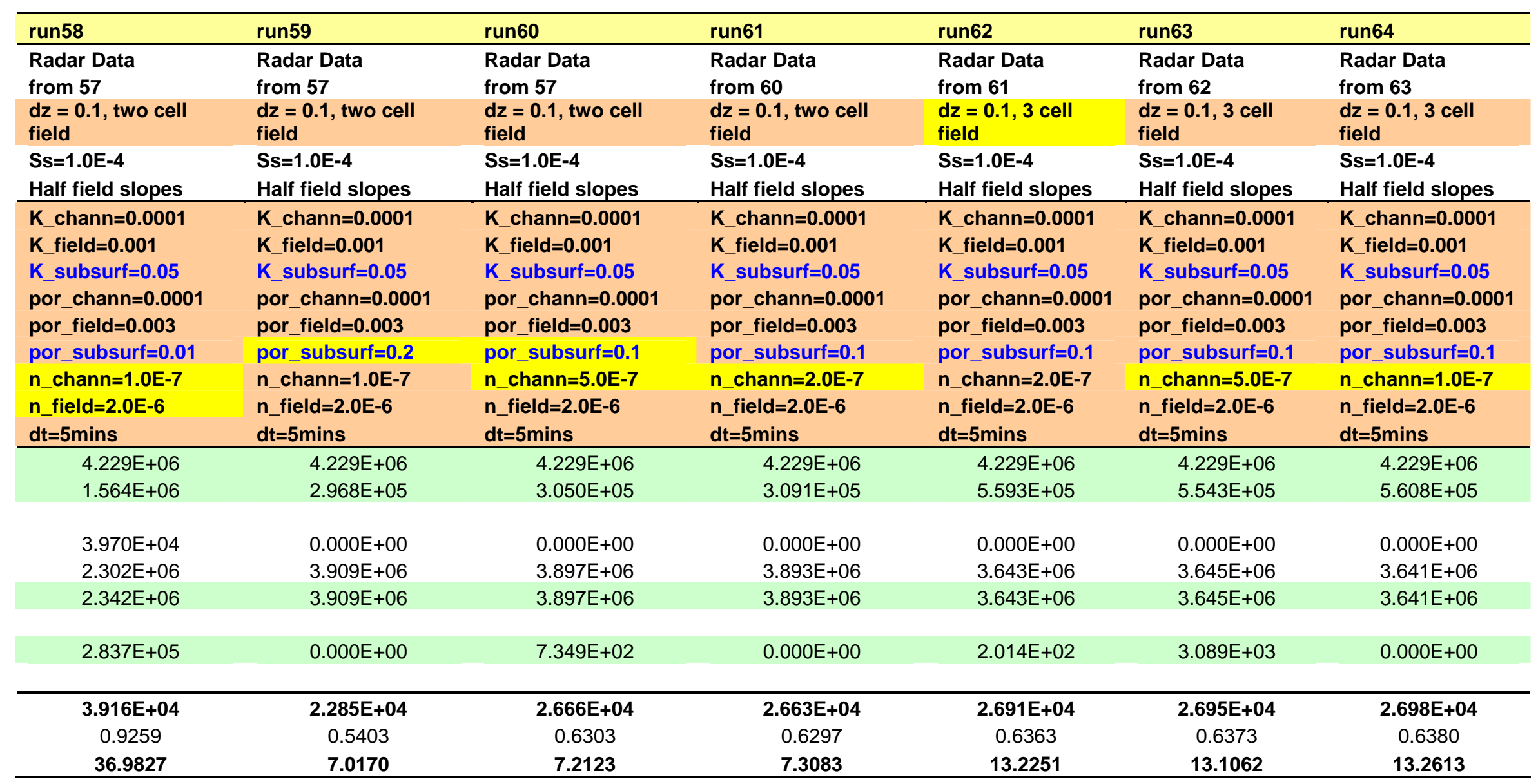


Table B.1 (Continued)

\begin{tabular}{|c|c|c|c|c|c|c|}
\hline run65 & run66 & run67 & run68 & run69 & run70 & run71 \\
\hline $\begin{array}{l}\text { Radar Data } \\
\text { from } 57\end{array}$ & $\begin{array}{l}\text { Radar Data } \\
\text { from } 65\end{array}$ & $\begin{array}{l}\text { Radar Data } \\
\text { from } 66\end{array}$ & $\begin{array}{l}\text { Radar Data } \\
\text { from } 65\end{array}$ & $\begin{array}{l}\text { Radar Data } \\
\text { from } 67\end{array}$ & $\begin{array}{l}\text { Radar Data } \\
\text { from } 69\end{array}$ & $\begin{array}{l}\text { Radar Data } \\
\text { from } 70\end{array}$ \\
\hline $\begin{array}{l}d z=0.1,3 \text { cell } \\
\text { field }\end{array}$ & $\begin{array}{l}d z=0.1,3 \text { cell } \\
\text { field }\end{array}$ & $\begin{array}{l}d z=0.1,3 \text { cell } \\
\text { field }\end{array}$ & $\begin{array}{l}d z=0.1,3 \text { cell } \\
\text { field }\end{array}$ & $\begin{array}{l}d z=0.1,3 \text { cell } \\
\text { field }\end{array}$ & $d z=0.1,3$ cell field & $\mathrm{dz}=0.1,3$ cell field \\
\hline $\mathrm{Ss}=1.0 \mathrm{E}-4$ & Ss=1.0E-4 & Ss=1.0E-4 & Ss=1.0E-4 & Ss=1.0E-4 & Ss $=1.0 \mathrm{E}-4$ & $\mathrm{Ss}=1.0 \mathrm{E}-4$ \\
\hline Half field slopes & Half field slopes & Half field slopes & Half field slopes & Half field slopes & Half field slopes & Half field slopes \\
\hline K_chann $=0.0001$ & K_chann $=0.0001$ & K_chann=0.0001 & K_chann $=0.0001$ & K_chann $=0.0001$ & K_chann $=0.0001$ & K_chann=0.0001 \\
\hline K_field=0.001 & $K \_$field=0.001 & $K \_$field $=0.001$ & $K \_$field $=0.001$ & $K \_$field $=0.001$ & $K \_$field $=0.001$ & $K \_$field $=0.001$ \\
\hline K_subsurf=0.05 & K_subsurf $=0.05$ & K_subsurf $=0.05$ & K_subsurf=0.05 & K_subsurf $=0.05$ & K_subsurf $=0.05$ & K_subsurf $=0.05$ \\
\hline por_chann=0.0001 & por_chann $=0.0001$ & por_chann=0.0001 & por_chann $=0.0001$ & por_chann=0.0001 & por_chann $=0.00009$ & por_chann=0.00009 \\
\hline por_field=0.003 & por_field=0.003 & por_field=0.003 & por_field=0.003 & por_field $=0.003$ & por_field=0.003 & por_field $=0.003$ \\
\hline por_subsurf=0.01 & por_subsurf $=0.01$ & por_subsurf $=0.01$ & por_subsurf=0.01 & por_subsurf=0.01 & por_subsurf $=0.01$ & por_subsurf $=0.01$ \\
\hline n_chann=1.0E-6 & n_chann=1.0E-7 & n_chann=1.0E-7 & n_chann=5.0E-7 & n_chann=1.0E-7 & n_chann=1.0E-7 & n_chann=3.0E-7 \\
\hline$n \_$field $=4.0 \mathrm{E}-6$ & $n \_$field=4.0E- 6 & $n \_$field $=5.0 E-6$ & $n \_$field $=4.0 \mathrm{E}-6$ & $n \_$field $=6.0 \mathrm{E}-6$ & $\mathrm{n} \_$field $=6.0 \mathrm{E}-6$ & $n \_$field $=6.0 \mathrm{E}-6$ \\
\hline$d t=5 \mathrm{mins}$ & $d t=5 \mathrm{mins}$ & $d t=5 \mathrm{mins}$ & $d t=5 \operatorname{mins}$ & $\mathrm{dt}=5 \mathrm{mins}$ & $d t=5 \mathrm{mins}$ & $\mathrm{dt}=5 \mathrm{mins}$ \\
\hline $4.229 E+06$ & $4.229 E+06$ & $4.229 E+06$ & $4.229 E+06$ & 4.229E+06 & $4.229 E+06$ & $4.229 E+06$ \\
\hline $1.327 E+06$ & $1.452 E+06$ & $1.351 \mathrm{E}+06$ & $1.386 \mathrm{E}+06$ & $1.262 E+06$ & $1.262 \mathrm{E}+06$ & $1.223 E+06$ \\
\hline $3.964 \mathrm{E}+04$ & $3.964 \mathrm{E}+04$ & $3.965 E+04$ & $3.964 E+04$ & 3.967E+04 & $3.967 E+04$ & 3.967E+04 \\
\hline $2.176 \mathrm{E}+06$ & $2.174 \mathrm{E}+06$ & $2.174 \mathrm{E}+06$ & $2.175 E+06$ & $2.174 \mathrm{E}+06$ & $2.174 \mathrm{E}+06$ & $2.175 E+06$ \\
\hline $2.215 E+06$ & $2.214 \mathrm{E}+06$ & $2.214 \mathrm{E}+06$ & $2.215 E+06$ & $2.214 \mathrm{E}+06$ & $2.214 \mathrm{E}+06$ & $2.214 \mathrm{E}+06$ \\
\hline $6.464 \mathrm{E}+05$ & $5.234 \mathrm{E}+05$ & $6.240 \mathrm{E}+05$ & $5.884 \mathrm{E}+05$ & $7.131 E+05$ & $7.131 E+05$ & $7.520 \mathrm{E}+05$ \\
\hline 4.021E+04 & $3.970 E+04$ & $3.991 E+04$ & $3.997 E+04$ & 3.994E+04 & $3.994 E+04$ & 3.998E+04 \\
\hline 0.9508 & 0.9386 & 0.9436 & 0.9452 & 0.9444 & 0.9444 & 0.9453 \\
\hline 31.3809 & 34.3391 & 31.9555 & 32.7737 & 29.8487 & 29.8487 & 28.9170 \\
\hline
\end{tabular}


Table B.1 (Continued)

\begin{tabular}{|c|c|c|c|c|c|}
\hline run72 & run73_LAX & run74_center & run75_outlet & run76_LAX & run77_LAX \\
\hline $\begin{array}{l}\text { Radar Data } \\
\text { from } 70\end{array}$ & $\begin{array}{l}\text { LAX Raingage } \\
\text { from } 72\end{array}$ & $\begin{array}{l}\text { Center Raingage } \\
\text { from } 72\end{array}$ & $\begin{array}{l}\text { Outlet Raingage } \\
\text { from } 72\end{array}$ & $\begin{array}{l}\text { LAX Raingage } \\
\text { from 73_LAX }\end{array}$ & $\begin{array}{l}\text { LAX Raingage } \\
\text { from 73_LAX }\end{array}$ \\
\hline$d z=0.1,3$ cell field & $d z=0.1,3$ cell field & $\mathrm{dz}=0.1,3$ cell field & $\mathrm{dz}=0.1,3$ cell field & $\mathrm{dz}=0.1,3$ cell field & $d z=0.1,3$ cell field \\
\hline Ss $=1.0 \mathrm{E}-4$ & $S s=1.0 E-4$ & $S s=1.0 E-4$ & $S s=1.0 E-4$ & $S s=1.0 E-4$ & Ss $=1.0 \mathrm{E}-4$ \\
\hline Half field slopes & Half field slopes & Half field slopes & Half field slopes & Half field slopes & Half field slopes \\
\hline K_chann $=0.0001$ & K_chann $=0.0001$ & K_chann $=0.0001$ & K_chann $=0.0001$ & K_chann $=0.0001$ & K_chann $=0.0001$ \\
\hline K_field $=0.001$ & K_field=0.001 & K_field $=0.001$ & K_field=0.001 & K_field $=0.001$ & K_field $=0.001$ \\
\hline K_subsurf=0.05 & K_subsurf $=0.05$ & K_subsurf $=0.05$ & K_subsurf=0.05 & K_subsurf=0.05 & K_subsurf $=0.05$ \\
\hline por_chann=0.00009 & por_chann=0.00009 & por_chann=0.00009 & por_chann=0.00009 & por_chann=0.00009 & por_chann $=0.00009$ \\
\hline por_field $=0.003$ & por_field $=0.003$ & por_field $=0.003$ & por_field $=0.003$ & por_field $=0.003$ & por_field=0.003 \\
\hline por_subsurf $=0.01$ & por_subsurf $=0.01$ & por_subsurf=0.01 & por_subsurf=0.01 & por_subsurf=0.01 & por_subsurf $=0.01$ \\
\hline n_chann=2.0E-7 & n_chann=2.0E-7 & n_chann=2.0E-7 & n_chann=2.0E-7 & n_chann=2.0E-7 & n_chann=2.0E-7 \\
\hline$n \_$field $=6.0 \mathrm{E}-6$ & $n \_$field $=6.0 \mathrm{E}-6$ & n_field $=6.0 \mathrm{E}-6$ & n_field $=6.0 \mathrm{E}-6$ & $n \_$field $=7.0 E-6$ & n_field=1.0E-5 \\
\hline$d t=5 \operatorname{mins}$ & $\mathrm{dt}=5 \mathrm{mins}$ & $\mathrm{dt}=5 \mathrm{mins}$ & $\mathrm{dt}=5 \mathrm{mins}$ & $\mathrm{dt}=5 \mathrm{mins}$ & $\mathrm{dt}=5 \mathrm{mins}$ \\
\hline $4.229 E+06$ & $5.817 \mathrm{E}+06$ & $4.514 \mathrm{E}+06$ & $3.443 E+06$ & $5.817 \mathrm{E}+06$ & $5.817 \mathrm{E}+06$ \\
\hline $1.241 \mathrm{E}+06$ & $2.432 \mathrm{E}+06$ & $1.408 \mathrm{E}+06$ & $6.692 E+05$ & $2.301 E+06$ & $1.978 \mathrm{E}+06$ \\
\hline $3.967 \mathrm{E}+04$ & $3.973 E+04$ & $3.969 \mathrm{E}+04$ & $3.963 \mathrm{E}+04$ & $3.975 E+04$ & $3.981 \mathrm{E}+04$ \\
\hline $2.174 \mathrm{E}+06$ & $2.171 E+06$ & $2.174 \mathrm{E}+06$ & $2.174 \mathrm{E}+06$ & $2.171 E+06$ & $2.171 E+06$ \\
\hline $2.214 \mathrm{E}+06$ & $2.211 E+06$ & $2.214 \mathrm{E}+06$ & $2.214 \mathrm{E}+06$ & $2.211 E+06$ & $2.211 E+06$ \\
\hline $7.344 \mathrm{E}+05$ & $1.123 \mathrm{E}+06$ & $8.496 \mathrm{E}+05$ & $5.255 \mathrm{E}+05$ & $1.254 \mathrm{E}+06$ & $1.577 \mathrm{E}+06$ \\
\hline 3.994E+04 & $5.157 E+04$ & $4.215 E+04$ & $3.455 E+04$ & $5.165 E+04$ & $5.169 E+04$ \\
\hline 0.9444 & 0.8866 & 0.9337 & 1.0034 & 0.8879 & 0.8885 \\
\hline 29.3379 & 41.8053 & 31.1948 & 19.4377 & 39.5603 & 34.0061 \\
\hline
\end{tabular}




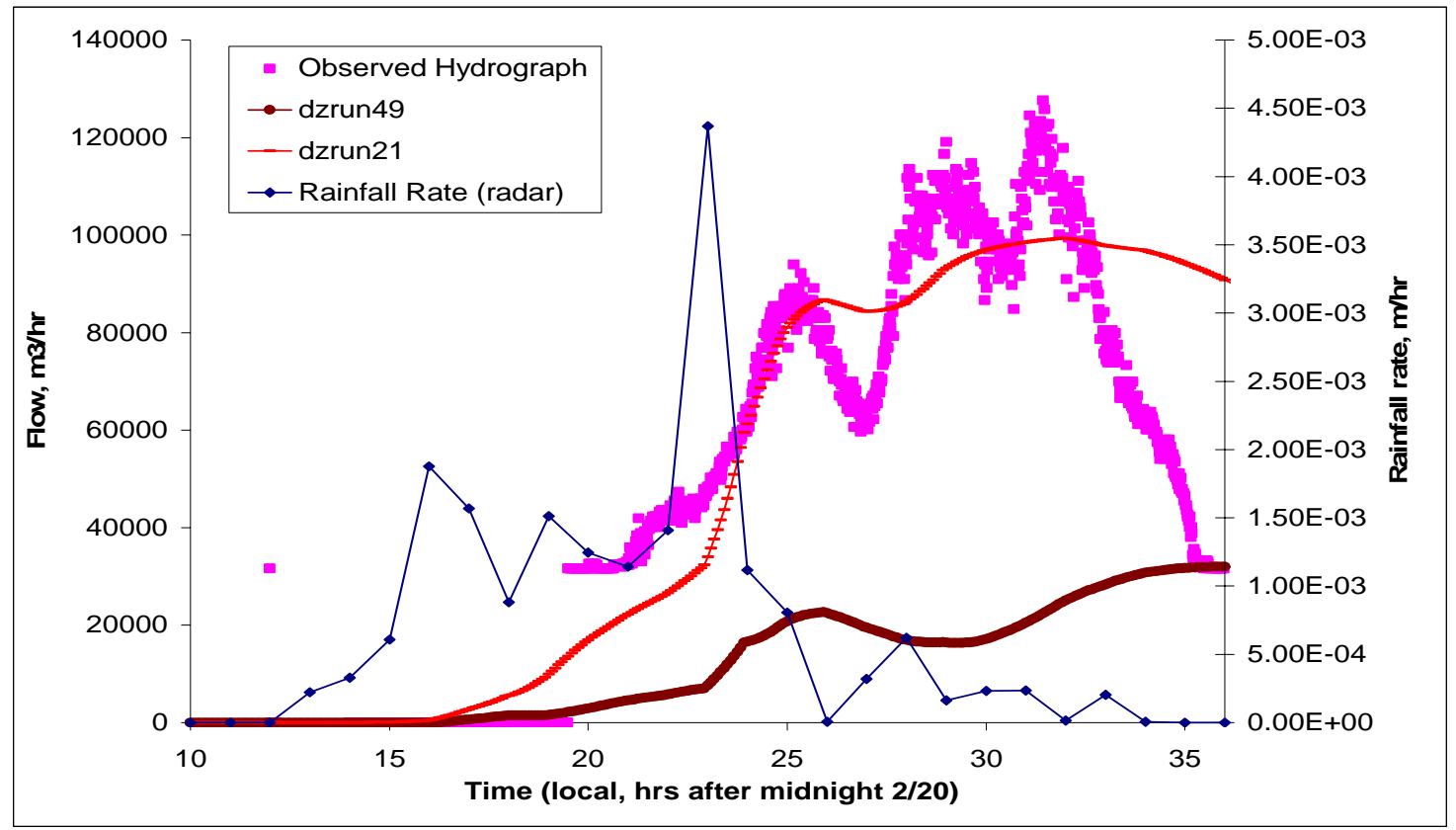

Figure B.1: Comparison of runs with (run49) or without (run21) a subsurface layer assigned.

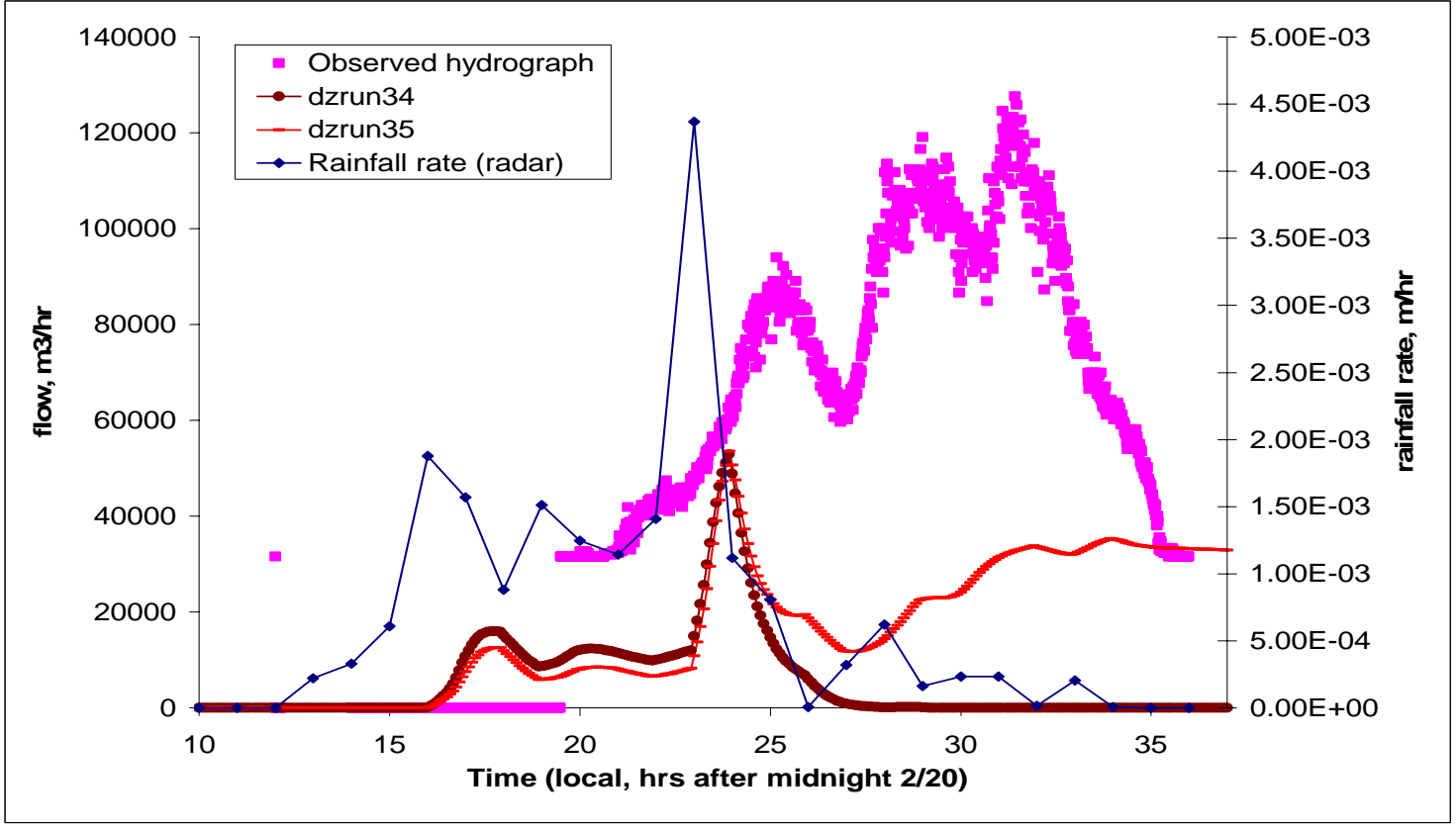

Figure B.2: Comparison of runs with different vertical cell size; run34 $(\mathrm{dz}=0.2)$ and run35 (dz=0.1) 


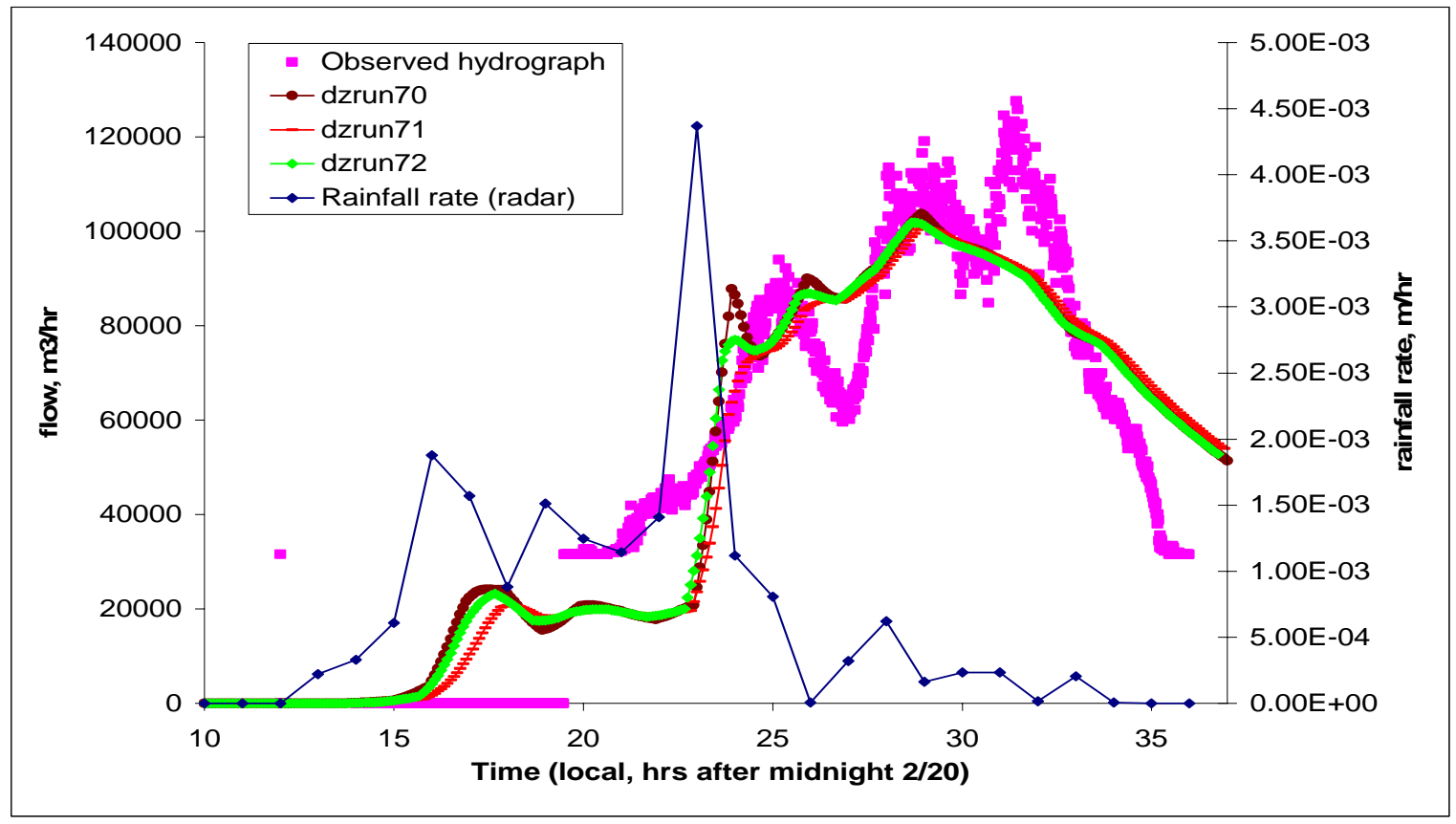

Figure B.3: Comparison of runs with different channel Manning's Coefficient; run70 (1.0E-7), run72 (2.0E-7), and run71 (3.0E-7).

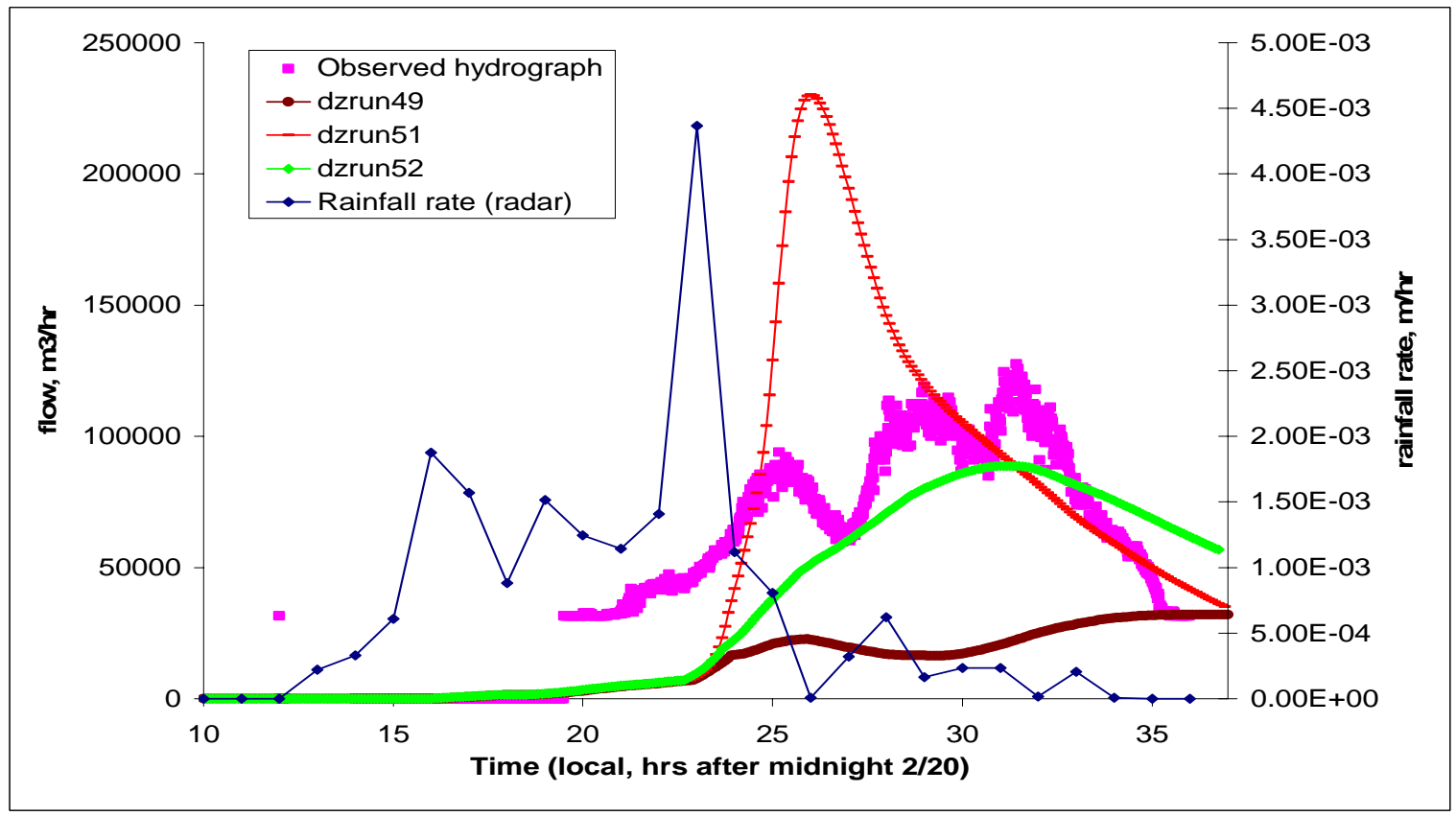

Figure B.4: Comparison of runs with different field Manning's Coefficient; run51 (1.0E-6), run52 (5.0E-6), and run49 (2.0E-5). 


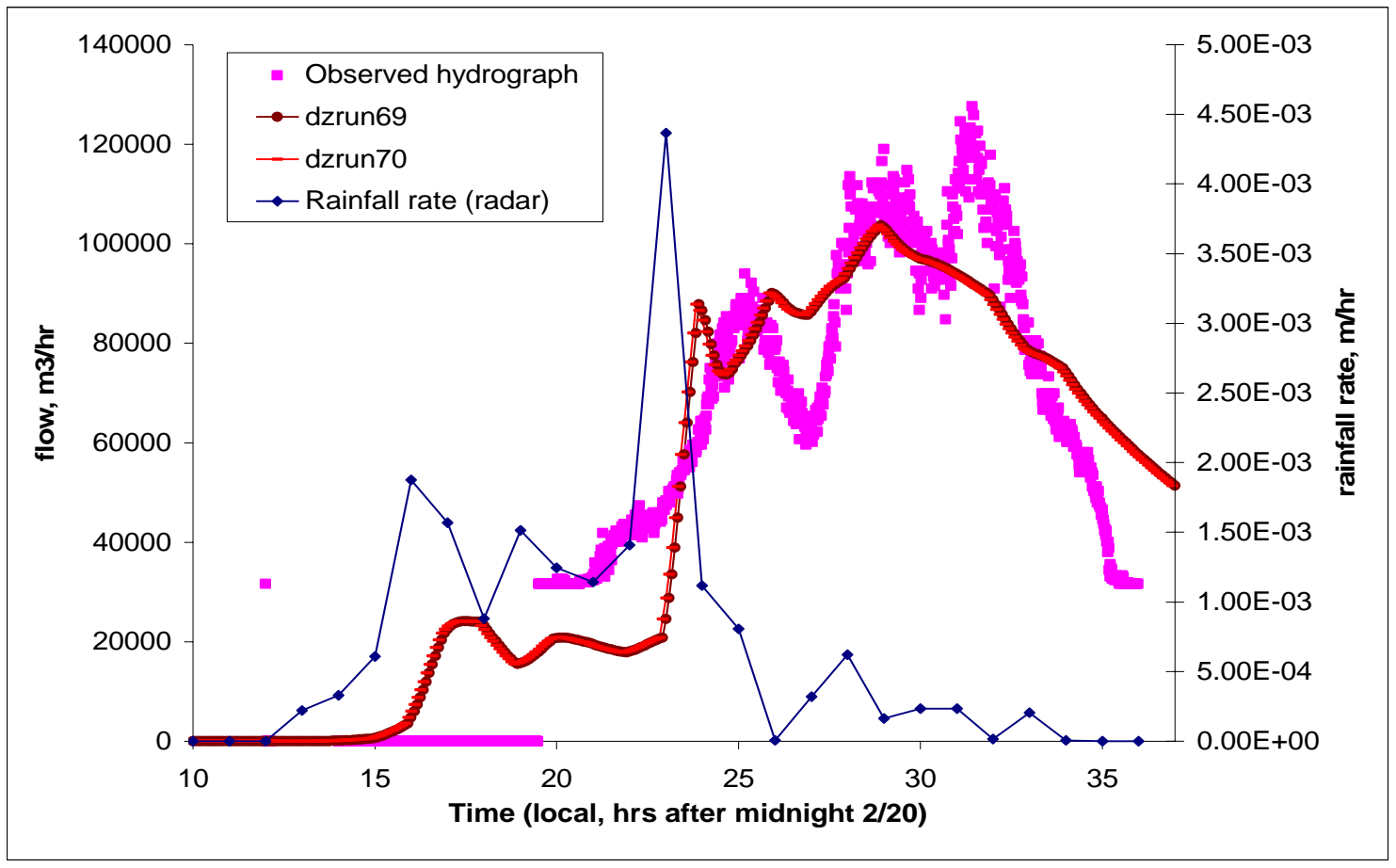

Figure B.5: Comparison of runs with different channel porosity; run70 (0.00009) and run69 (0.0001)

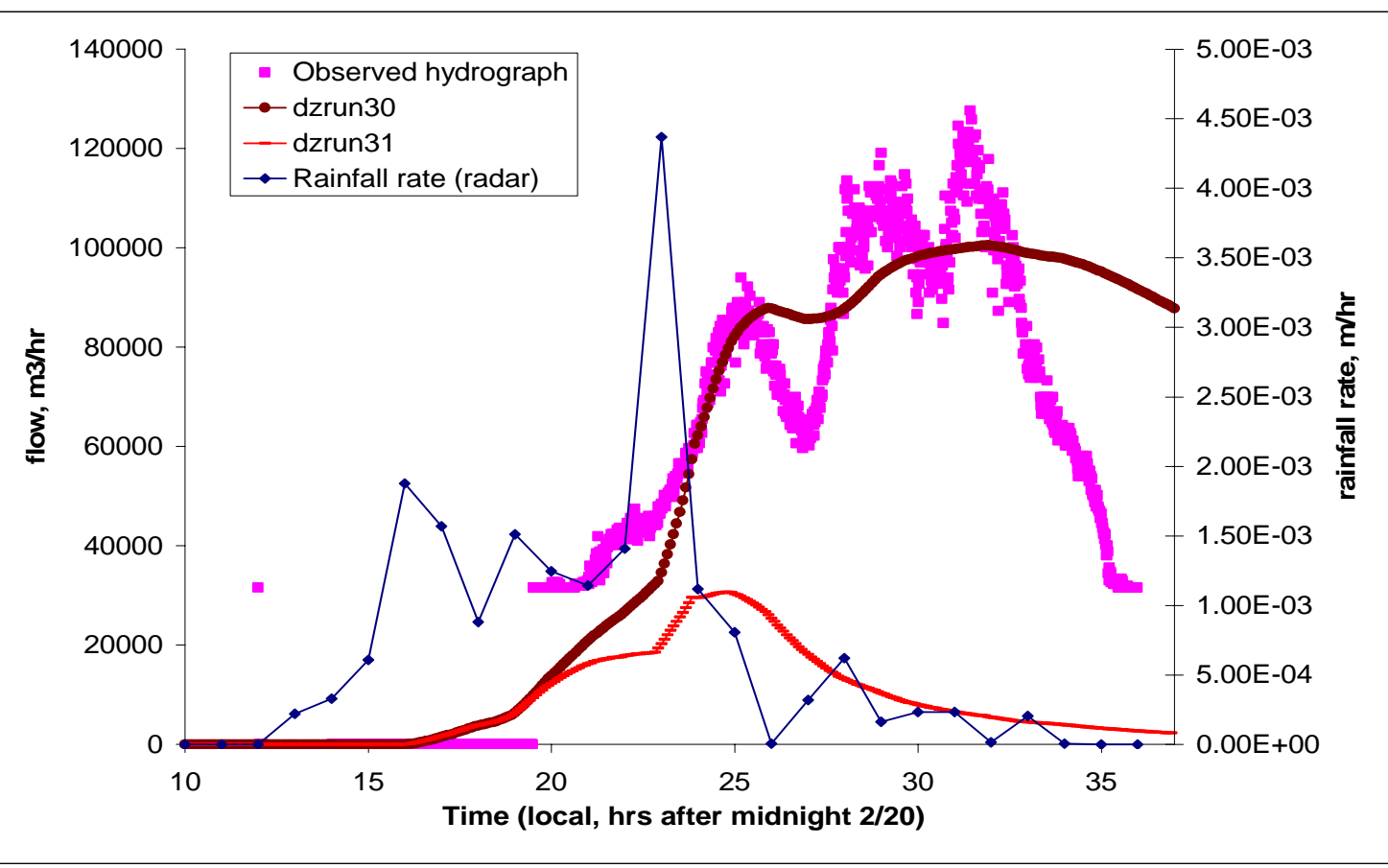

Figure B.6: Comparison of runs with different field porosity; Run30 (0.001) and run21 (0.01) 


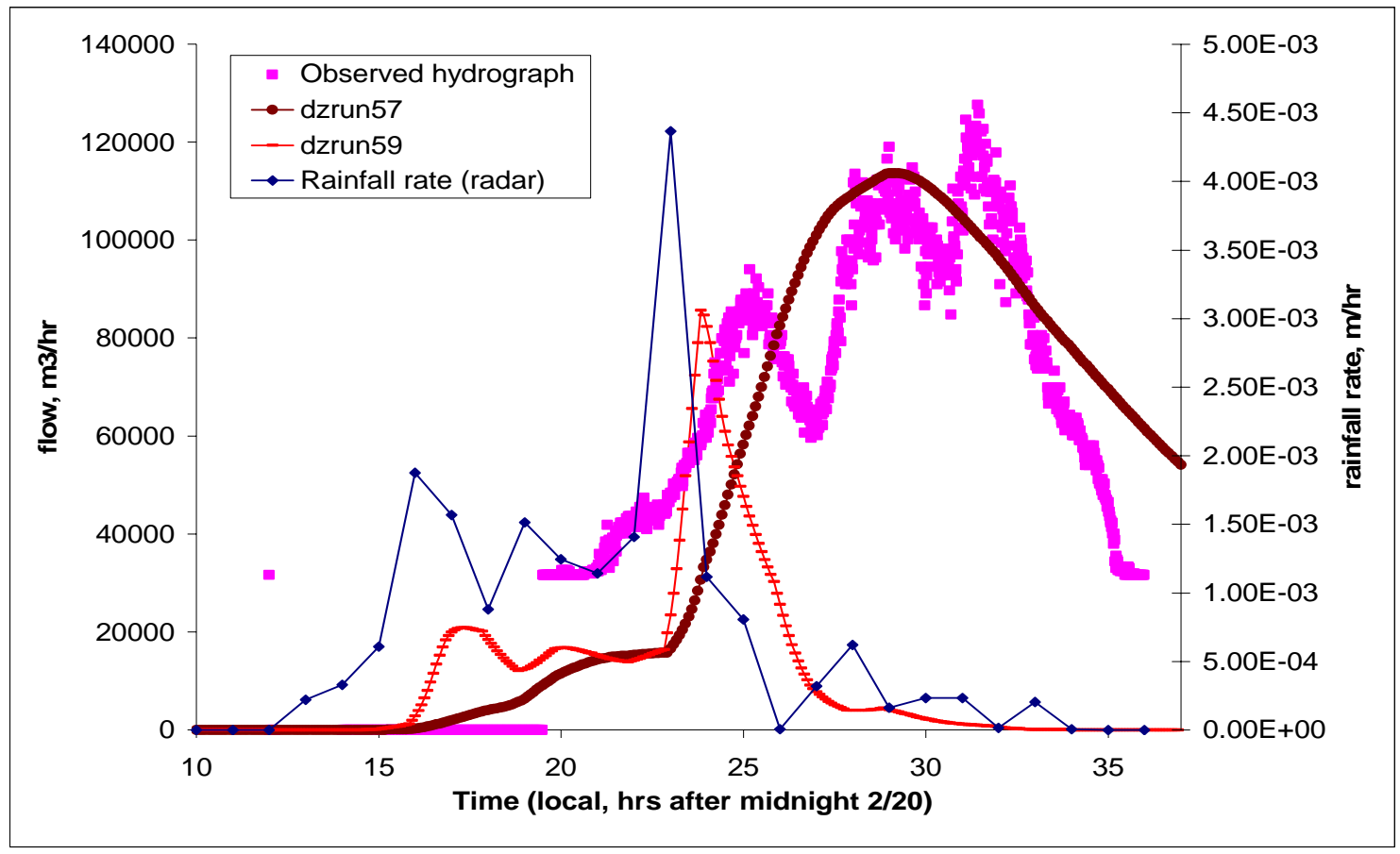

Figure B.7: Comparison of runs with different subsurface porosity;

Run57 (0.01) and run59 (0.2)

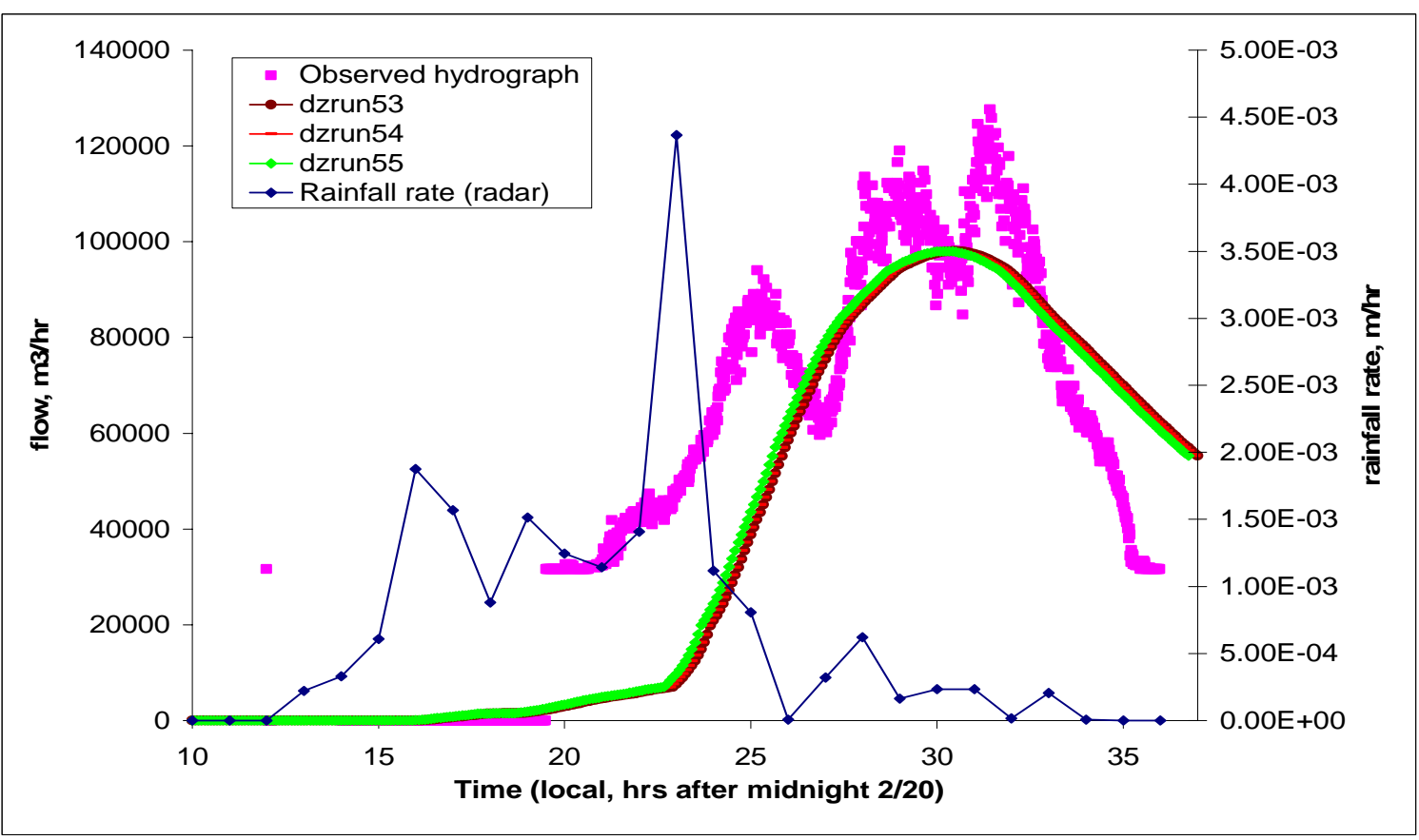

Figure B.8: Comparison of runs with different field hydraulic conductivity; Run55 (0.0005), run54 (0.001), and run53 (0.003) 


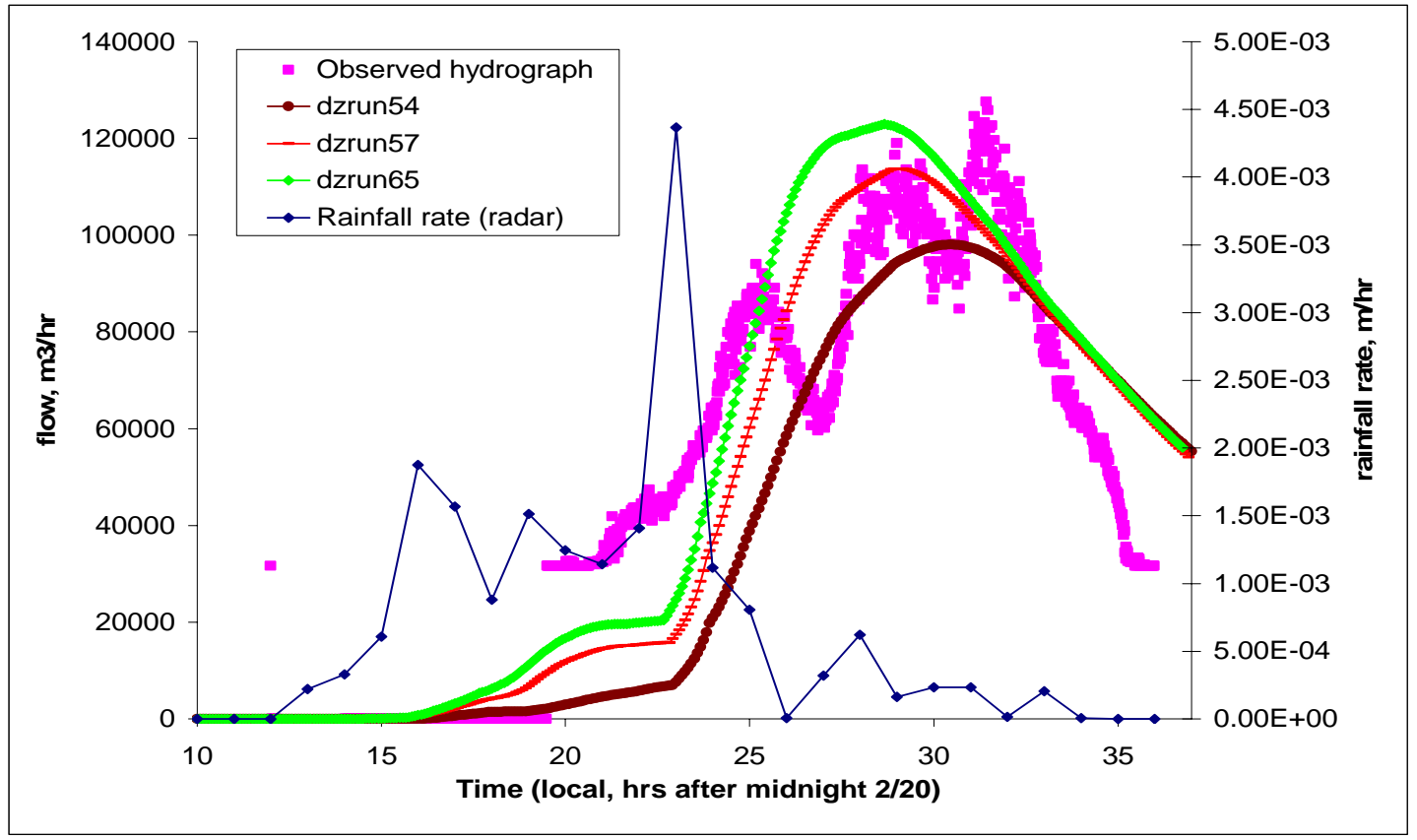

Figure B.9: Comparison of runs with different surface layer thickness; Run54 (1 layer), run57 (2 layers), and run65 (3 layers)

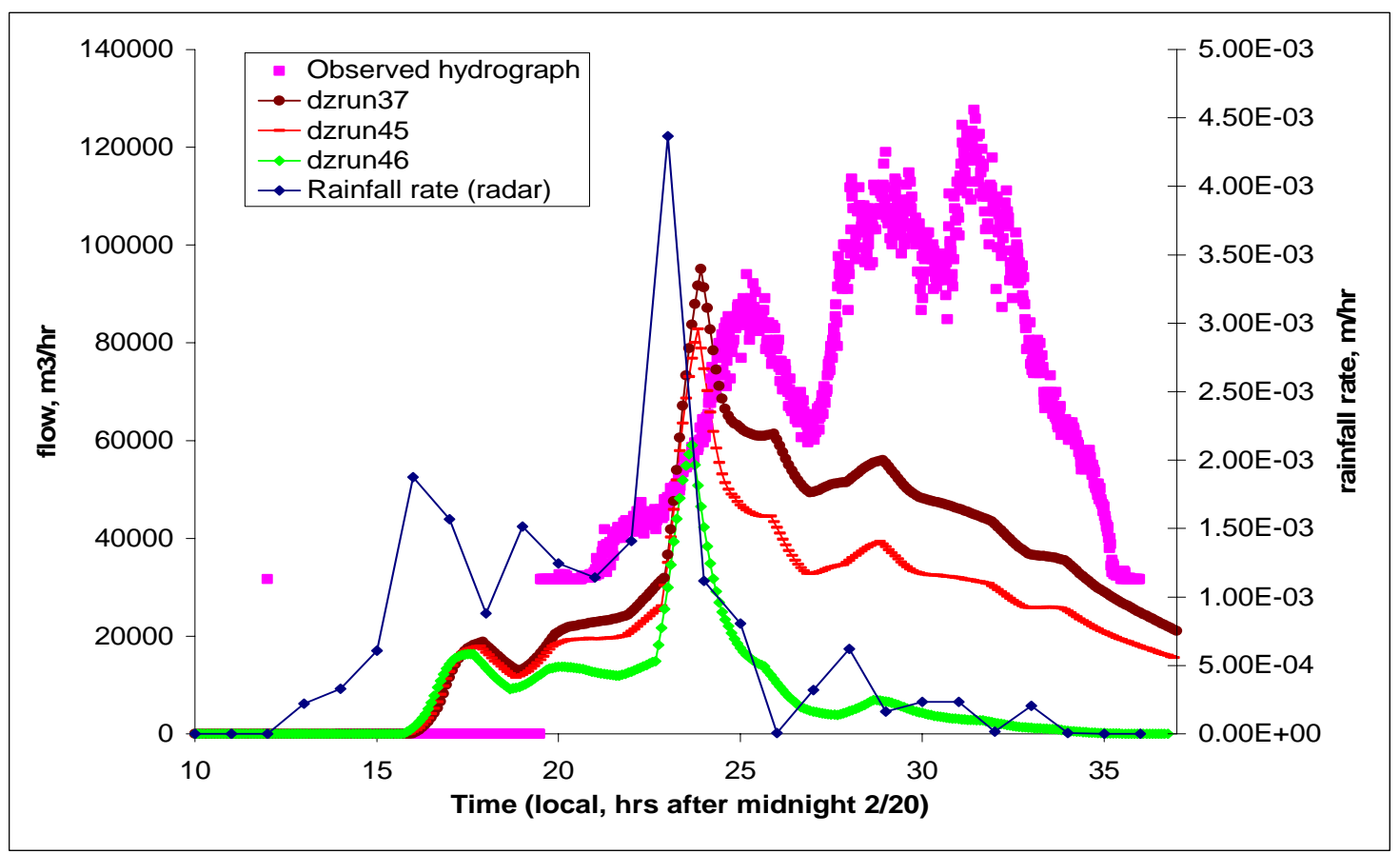

Figure B.10: Comparison of runs with different field slopes;

Run37 (0.5*processed field slopes), run45 (0.25*processed field slopes), and run46 (0.05* processed field slopes). 